Chapter 4

\title{
Ecotoxicological Behavior of some Cationic and Amphoteric Surfactants (Biodegradation, Toxicity and Risk Assessment)
}

\author{
Stefania Gheorghe, Irina Lucaciu, Iuliana Paun, \\ Catalina Stoica and Elena Stanescu
}

Additional information is available at the end of the chapter

http://dx.doi.org/10.5772/56199

\section{Introduction}

Detergents industry is a competitive industry, with a large opening to innovation and economical development. Although very good for sanitation, the big domestic and industrial detergents consumption has a significant contribution to surfactants concentrations increase in towns' sewage and implicit to surface water and groundwater contamination [1] (Figure 1). The negative effects manifested by the presence of surfactants in surface water are mostly due to superficial - active proprieties - detergents surfactants characteristic, indifferently of class type. In accordance with molecule charge, the surfactants are grouped in four categories: anionic, cationic, nonionic and amphoteric [2].

This chapter is focus on cationic and amphoteric surfactants frequently used in laundry and dishes detergents, fabric softeners, personal care products and biocides. Cationic and amphoteric surfactants control was not required until 2004, when the European Detergents Regulation no. 648 entered into force, especially because there were no standard methods for quantitative determination of these types of surfactants [3]. Also, the biodegradation assessing was not requested and there is no European standard method for this testing. These surfactants are not currently limited by national or international norms relating to waste waters and surface waters quality. Literature references concerning ecotoxicological characteristics and risk assessment of cationic and amphoteric surfactants are relatively reduced. 


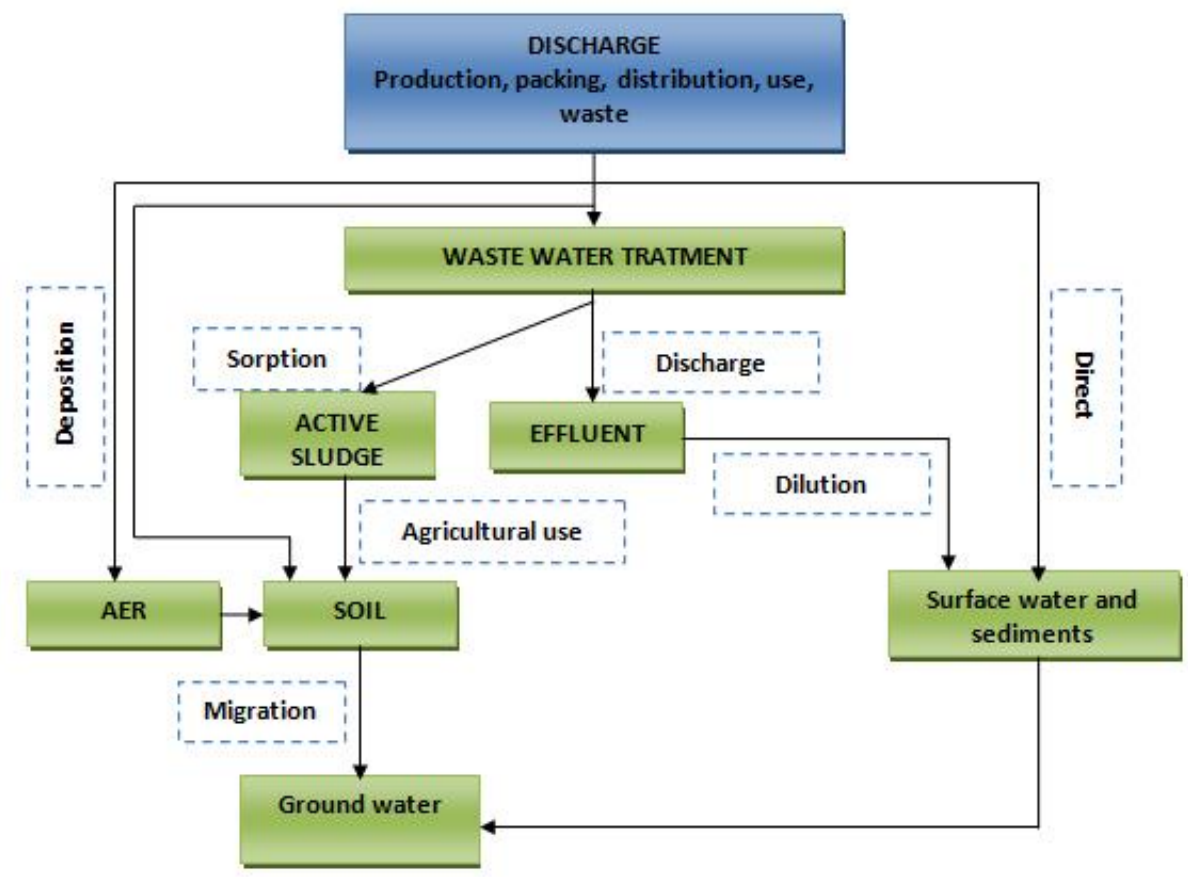

Figure 1. Surfactants environmental contamination [1]

\section{Detergents legislative framework}

At European level, detergents and cleaning products have a special place in legislative framework of European Community because are manufactured in big quantity and they may affect the environment during both manufacture and using processes. In the last years surfactants biodegradability was the most significant problem.

The chapter broaches a new and important actuality theme at international level, namely the implementation of the most important European legislative regulations concerning detergents and cleaning products - Regulation (EC) no. 648/2004 and it amendments. The present Regulation establish strict rules to assure the free circulation of detergents - products for consummators and industrial and institutional products and implicit of surfactants on UE market, so that the human health and environmental protection to be guaranteed at high level. A significant request of Regulation is that each producer/ importer / distributor to attest ultimate aerobic biodegradability of surfactants used in detergents [3]. 
In 2006 have become applicable Regulation (EC) no. 907/2006 - through that is follow the assurance of a environmental higher level protection(impose for detergents (a) biodegradability and (b) conformity with at least one ultimate biodegradability tests specified in Annex III) and human health (impose requests concerning the information's which must be written on the detergents packages) [4].The last important amendment of Detergents Regulation, is the norm (EU) no. 259/2012 which standardized the use of phosphates and other phosphorous compounds in household laundry detergents and automatic dishwashing for consumers.

Also at European level is applicable the Technical Guidance for stratified approach of Regulation (EC) no. 648/2004, emitted in 2005, which provide that the use of surfactants in detergents is allowable unless that surfactants fulfills the aerobe degradation criteria even if are subject to direct testing as individual substance (mineralization) or through interpolation. For the surfactants which not success to pass one between these mineralization tests, but which respect the primary biodegradability criteria may request a derogation for its utilization in industrial and institutional detergents. These derogations are obtained, in base of environment safety concerning the assessments for the metabolites which may result at the surfactant biodegradation. All assessments will be stratified performed (Figure 2), in accordance with a phased process which will provide all the information's concerning the environmental risks of the recalcitrant metabolites resulted after biodegradation. For passing the complementary risk assessment it is necessary to show that the PEC does not surpass the PNEC of the metabolites [5].

Environmental European legislation showed that only anionic and non-ionic surfactants have set limit values, while the cationic and amphoteric surfactants have not imposed limits in waste waters or surface water, even though they have a frequent use in cleaning products and biocides.

At international level exist some actions to encourage the producers to obtain safe cleaning products, transposed in Regulation (EC) no. 66/2010 concerning UE ecological label. The ecological labeling of products is facultative and promotes the security of detergents on the entire life cycle: from the raw materials, production process, packing, distribution, use, recycling and elimination. Through ecological labeling is trying the reduction of hazardous chemicals use, with effects on water, air and soil and of carcinogenic and allergic risks. The detergents with the European Ecolabel contain no hazardous substances to the aquatic environment; have a increased biodegradability, and an efficient use that does not cause damage to the environment [6].

Beginning with February 2009, the most representative European associations (AISE, CESIO, CEFIC) have informed about their initiative to undertake further researches in order to: establish the surfactants ecotoxicity and assess the potential environmental risk; develop an improved method for measuring the anaerobic biodegradability under sludge digester conditions; and to evaluate the biodegradation of the main organic non-surfactant ingredients from detergents $[7,8]$. 


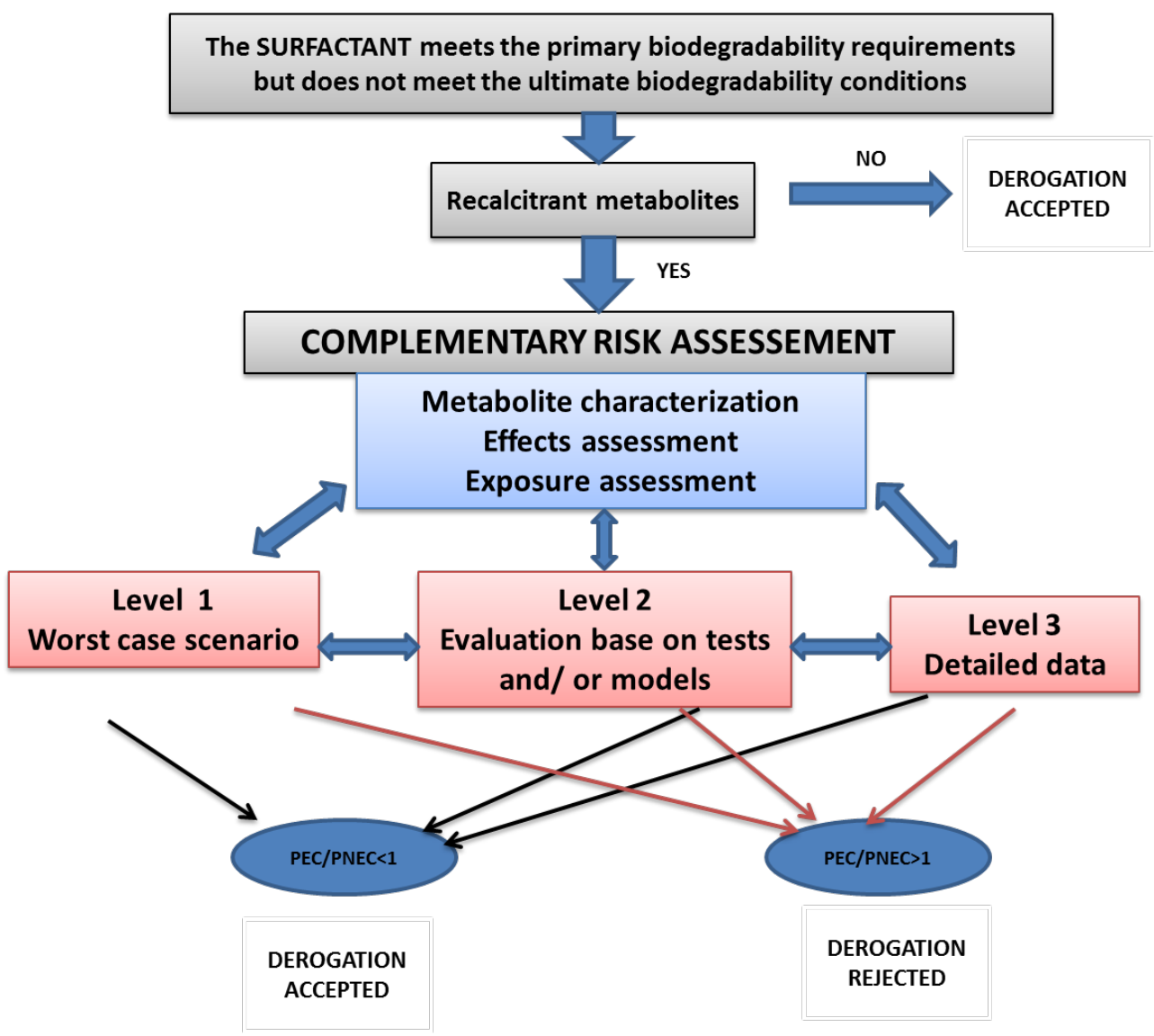

Figure 2. Complementary risk assessment, adapted from CESIO and AISE

\section{Surfactants ecotoxicity}

In literature there are many studies to evaluate the ecotoxicity of anionic and non-ionic surfactants, and therefore future research should be directed especially to elucidate the toxic effects of cationic and amphoteric surfactants whose ecotoxicological profile is unknown, and their physical and chemical properties can significantly interfere in the results of the toxicological studies.

According to CESIO reports, half of detergents consumption has been used in domestic applications and other half in cosmetic industry, metal processing, paper and leather industry. In 2007 the most used surfactants were anionic and non-ionic surfactants covering half of 
produced surfactants [9]. In 2008 it was estimated that in Eastern Europe were used annually $>4.2$ million tons of detergents and 1.2 million tons of softeners, up to 2006 [10].

It was found that during 1990-2010, in the international waste waters were identified following surfactants concentrations: anionic 330 - $9450 \mu \mathrm{g} / \mathrm{L}$; nonionic 5 - $395 \mu \mathrm{g} / \mathrm{L}$; cationic 0.1 - $325 \mu \mathrm{g} /$ $\mathrm{L}$ (even $6000 \mu \mathrm{g} / \mathrm{L}$ in hospitals waste waters) [1,10-12]. No data on amphoteric surfactants were identified.

In surface water were estimated following concentrations: anionic $<4-81 \mu \mathrm{g} / \mathrm{L}$; nonionic $<0.002$ - $31 \mu \mathrm{g} / \mathrm{L}$; amphoteric $<0.01$ to $3.8 \mu \mathrm{g} / \mathrm{L}$; cationic $<0.1$ - $34 \mu \mathrm{g} / \mathrm{L}[13,14]$.

According to our research studies, in Romania, in the last 10 years, the concentrations of surfactants in waste waters and surface waters were: anionic $0.3-9 \mathrm{mg} / \mathrm{L}$; non ionic $0.05-4 \mathrm{mg} /$ $\mathrm{L}$; cationic $0.03-0.35 \mathrm{mg} / \mathrm{L}$; amphoteric $0.02-0.05 \mathrm{mg} / \mathrm{L}$.

According with international regulations, the first criteria in environmental risk assessment of surfactants is to assess their biodegradation. Biological degradation of surfactants could be performed by a several tests which ones decrease in order of stringency as followed: Ultimate / Readily biodegradability tests, Inherent biodegradability tests, Rapidly biodegradability tests and Primary biodegradability tests [15].

The ultimate biodegradability tests are recommended to assess the biodegradation of surfactants, because by using them, we can control whether surfactants are degraded in the presence of microorganisms to the metabolites (non-surfactants), mineral salts, biomass and $\mathrm{CO}_{2}$ (the measured parameters).

Biodegradability testing methodology is required by Detergents Regulation no. 648/2004 (Annexes no. III and VIII), which provides degradation limits of surfactants used in cleaning products [16]. All data concerning biodegradability, use informations, consumption and current conditions of environmental exposure of the substance, make it possible to PEC (Predict Environment Concentration) of the substance.

Legislation, in force requires a primary biodegradability of cationic and amphoteric surfactants greater than $80 \%$. In terms of ultimate biodegradability (Table 1), these compounds are finally degraded under aerobic ( $>60 \%-100 \%)$ and anaerobic conditions (64-100\%). Some problems are highlighted for quaternary cationic surfactants and amphoteric alkyl betaines in both conditions.

Surfactants products have some negative effects on surface waters as: decreasing of air / water oxygen transfer, water quality damage because of foam, sorption on solid particles preventing the sedimentation, reduction of river self-cleaning capacity, affecting the gases transfer between the microorganism cells and have a great toxicity on the aquatic organisms in trophic level.

Toxicological behavior is the second criterion in environmental risk assessment. Detergents show toxic effects for all aquatic organisms if there are present in sufficient amounts and that include biodegradation products. Most fish die when the detergent concentration in water is about $15 \mathrm{mg} / \mathrm{L}$ and also, at concentrations above $5 \mathrm{mg} / \mathrm{L}$ cause the 
death of eggs and affecting the fish reproduction [17]. Another study reported that 0.4 to $40 \mathrm{mg} / \mathrm{L}$ of detergents induce toxic effects by damaging the gills, growth delay, alteration of feeding process and the inhibition of the organs chemoreceptors in vertebrates. In case of invertebrates at detergent concentrations below that $0.01 \mathrm{mg} / \mathrm{L}$, the reproduction, growth and development are disturbed [18].

Generally, the toxicity of surfactants is influenced by a range of abiotic and biotic factors. The abiotic factors, eg. physico-chemical properties of water $(\mathrm{pH}$, hardness, other polar substances, dissolved oxygen, suspended matters) lead to a low bioavailability of the compound to aquatic organisms. Also, the physico-chemical properties of the surfactant (the size of aliphatic chain [26, 32], type of surfactant, absorption capacity and concentration) have a great influence of the toxicity level. Biotic factors generally refer to: age of organisms, tested species [33, 34], sensitivity between species [35] and acclimatization at very low concentrations of detergent $[10,18]$.

As long as, it is practically impossible to perform bioassays on all aquatic food chain, in order to assess the ecotoxicological effects of chemicals (Figure 3), at international level, certain representative aquatic food chain species were established, as follows: microorganisms, algae, crustaceans (benthic and planktonic) and fish. With the REACH Regulation implementation [36], the eco-toxicity tests were diversified by applying of microbiotests [37] as an alternative to conventional methods, in order to reduce or replace animal testing (highlighted in the OECD, ISO and EPA methodology - Table 2).

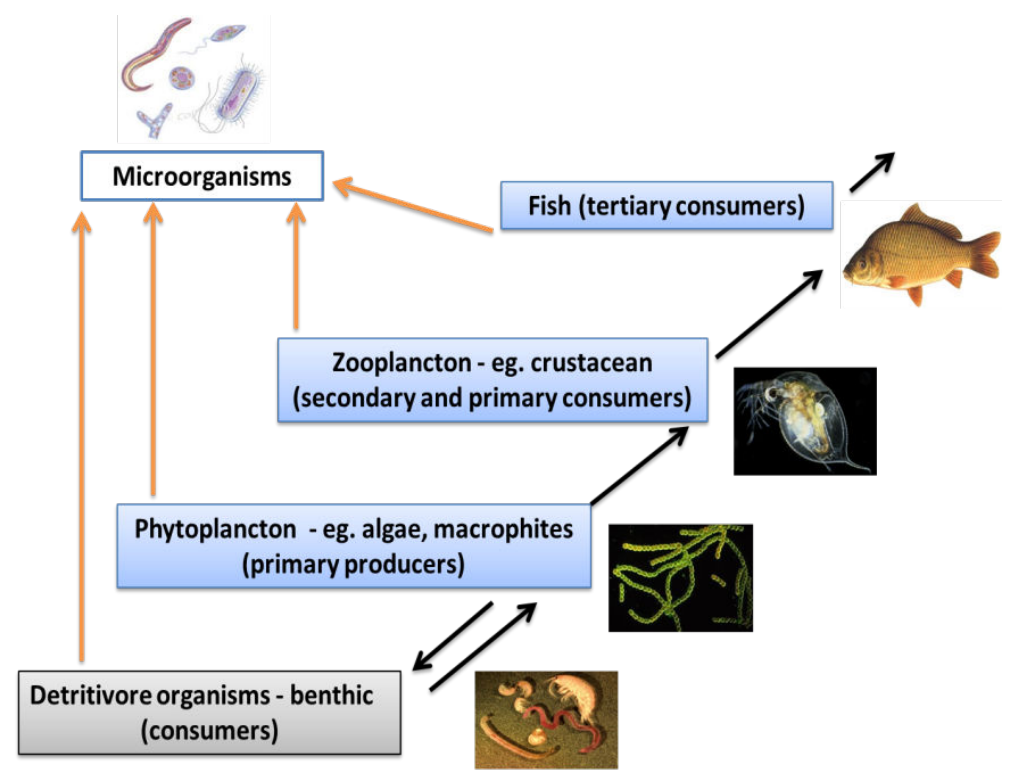

Figure 3. Aquatic food chain 


\section{Surfactant type}

\section{Biodegradability}

\section{CATIONIC SURFACTANTS}

\begin{tabular}{|c|c|}
\hline Esterquats & $79 \%$ (ISO 10708) [1] \\
\hline \multirow[t]{6}{*}{ (DEEDMAC, HEQ, TEAQ, etc.) } & $80->85 \%$ (OECD 301B) $[11,19]$ \\
\hline & $90 \%(\mathrm{OECD} 301 \mathrm{~F})[20]$ \\
\hline & $75 \%$ (OECD 302B) [11] \\
\hline & $>60 \%(\mathrm{OECD} 301 \mathrm{D})[21]$ \\
\hline & $64-100 \%$ (ECETOC) [9] \\
\hline & $73-100 \%$ (ECETOC) ) $[11,20]$ \\
\hline \multirow[t]{2}{*}{ Diesterquats } & $92 \%(O E C D$ 301A) [22] \\
\hline & $90 \%(\mathrm{OECD} 301 \mathrm{~B})[23]$ \\
\hline Ammonium quaternary compounds & $>5 \%$ (OECD 301D) [1] \\
\hline \multirow[t]{2}{*}{ (eg. DSDMAC, DTDMAC, ATMAC) } & $0-24 \%(E C E T O C)[9]$ \\
\hline & $40-81 \%(O E C D$ 301F, 301B, 302A) [24] \\
\hline $\begin{array}{l}\text { Other cationic surfactants } \\
\text { (hydrogenated chain) }\end{array}$ & $63 \%(\mathrm{OECD} 301 \mathrm{~A})[22]$ \\
\hline \multicolumn{2}{|l|}{ AMPHOTERIC SURFACTANTS } \\
\hline Alkyl betaines & $99 \%(\mathrm{OECD} 301 \mathrm{~A})[22]$ \\
\hline \multirow[t]{3}{*}{ (dimethylaminebetaines / alkyl amidobetaines) } & $0 \%->60 \%$ (ECETOC) [9] \\
\hline & $>60 \%(T h O D)$ (OECD301D) [25] \\
\hline & $60-100 \%$ (ISO 14593) [26] \\
\hline Hidroxysulfobetaines & $40-47 \%[25,27]$ \\
\hline Imidazoline derivatives (cocoamphoacetates / alkyl & $>60 \%$ (ECETOC) [9] \\
\hline \multirow[t]{6}{*}{ amphoacetates/ alkylamino propionates) } & $>60 \%[25]$ \\
\hline & $80-90 \%$ (OECD 301E) [1] \\
\hline & $79.8 \%($ ECETOC) [9] \\
\hline & $80-100 \%(I S O 14593)[26]$ \\
\hline & $60-79 \%$ (OECD 301D, 301E) [27] \\
\hline & $2.5 \%$ ThGP (ISO 11734) [27] \\
\hline \multirow[t]{5}{*}{ Cocamidopropylbetaine / Coco alkyl derivatives } & $82 \%$ (ThOD), 95\% (COD) (OECD 301C) [28] \\
\hline & $90-100 \%[29,30]$ \\
\hline & $97 \%(O E C D$ 301A) [22] \\
\hline & $57-84 \%$ (ThOD) (OECD 301D) [25] \\
\hline & $45-75 \%$ ThGP (ISO 11734) [27] \\
\hline \multirow[t]{2}{*}{ Other amphoteric surfactants } & $97 \%(D O C)(O E C D$ 303A) [31] \\
\hline & $60 \%$ (ThCO2), 70\% (DOC)( OECD 301B) [31] \\
\hline
\end{tabular}

Table 1. Cationic and amphoteric surfactants biodegradability 
Usually, it is recommended to perform the standardized OECD and ISO methodology for assessing of ecotoxicity. The toxicity level of surfactants is assessed using tests batteries covering all trophic level of aquatic environment, and it is recommended the acute and chronic tests in classical or alternative system. Both cationic and amphoteric surfactants cause high or moderate acute toxicity on fish, crustaceans, algae and bacteria. It is noted that the ranges of toxicity values are very large and diversified, even for the same aquatic organism or test method and for this reason the literature is very permissive (Table no.3).

\begin{tabular}{|c|c|c|c|c|}
\hline No. & Toxicity tests & OECD & ISO/EPA & Microbiotests \\
\hline \multicolumn{5}{|c|}{ Vertebrates (tertiary consumers) } \\
\hline 1. & $\begin{array}{l}\text { Fish acute toxicity test, (static } \\
\text { test/ semi static test/ dynamic } \\
\text { test) }\end{array}$ & 203 & $\begin{array}{l}\text { ISO } 7346: \\
1,2,3 \\
\text { ISO } 13216 \\
\text { ISO } 10229 \\
\text { ISO/CD } \\
15088-1 \\
\text { EPA } 2000.0 \\
2004.0 ; 2006.0\end{array}$ & \multirow{7}{*}{$\begin{array}{l}\text { (Q)SAR and ECOSAR methods } \\
\text { Fish cell cytotoxicity tests } \\
\text { Genetic tests } \\
\text { Endocrine tests } \\
\text { [approved by ICCVAM, ECVAM, OECD, } \\
\text { EPA, SETAC, ECETOC in order to reduce / } \\
\text { replace the animals used in toxicity tests } \\
\text { according to REACH] }\end{array}$} \\
\hline 2. & $\begin{array}{l}\text { Fish, prolonged toxicity test- } 14 \\
\text { days study }\end{array}$ & 204 & - & \\
\hline 3. & Fish juvenile growth tests & 215 & - & \\
\hline 4. & Fish, early-life stage toxicity test & 210 & - & \\
\hline 5. & $\begin{array}{l}\text { Fish, Short term toxicity test on } \\
\text { embryonic stages }\end{array}$ & 212 & $\begin{array}{l}\text { ISO } 12890 \\
\text { EPA } 1000.0\end{array}$ & \\
\hline 6. & Bioaccumulation in fish & 305 & - & \\
\hline 7. & Fish sex development test & 234 & - & \\
\hline \multicolumn{5}{|c|}{ Zooplankton (primary and secondary consumers) } \\
\hline 8. & $\begin{array}{l}\text { Daphnia magna, acute } \\
\text { immobilization test (static and } \\
\text { semi static test) }\end{array}$ & 202 & $\begin{array}{l}\text { ISO } 6341 \\
\text { ISO } 14669 \\
\text { EPA 2002.0; } \\
2021.0\end{array}$ & \multirow{3}{*}{$\begin{array}{l}\text { Daphtoxkit F, Daphnia IQ Test } \\
\text { (Daphnia magna, Daphnia pulex) } \\
\text { Thamnotoxkit F (Thamnocephalus } \\
\text { platyrus) } \\
\text { Rotoxkit F (Brachinous calyciflorus) } \\
\text { Rotoxkit M (Brachinous splicatilis) } \\
\text { Ceriodaphtoxkit K (Ceriodaphnia dubia) } \\
\text { Ostracodtoxkit (Heterocypris incongruens) }\end{array}$} \\
\hline 9. & $\begin{array}{l}\text { Daphnia magna, reproduction } \\
\text { test }\end{array}$ & 211 & $\begin{array}{l}\text { ISO } 10706 \\
\text { EPA } 1002.0\end{array}$ & \\
\hline 10. & $\begin{array}{l}\text { Daphnia magna, chronic toxicity } \\
\text { test }\end{array}$ & - & $\begin{array}{l}\text { ISO } 10706 \\
\text { ISO/DIS } 20665 \\
\text { ISO/WD } \\
20266\end{array}$ & \\
\hline \multicolumn{5}{|c|}{ Phytoplankton (primary producers) } \\
\hline 11. & $\begin{array}{l}\text { Fresh algal growth inhibition test, } \\
\text { Pseudokirchnerilla subcapitata }\end{array}$ & 201 & $\begin{array}{l}\text { ISO } 8692 \\
\text { SR } 13328 \\
\text { EPA } 1003.0\end{array}$ & $\begin{array}{l}\text { Algaltoxkit F (Raphidocelis subcapitata, } \\
\text { Selenastrum capricornutum, Chlorella } \\
\text { vulgaris) }\end{array}$ \\
\hline
\end{tabular}




\begin{tabular}{|c|c|c|c|c|}
\hline No. & Toxicity tests & OECD & ISO/EPA & Microbiotests \\
\hline \multicolumn{5}{|c|}{ Benthic organisms } \\
\hline 12. & $\begin{array}{l}\text { Water - Sediment toxicity, } \\
\text { Chironomus riparius }\end{array}$ & $\begin{array}{l}218 \\
219\end{array}$ & - & $\begin{array}{l}\text { Ostracodtokit(Heterocypris incongruens) } \\
\text { Microtox (Vibrio fischeri) }\end{array}$ \\
\hline \multicolumn{5}{|c|}{ Aquatic floating plants } \\
\hline 13. & $\begin{array}{l}\text { Growth inhibition tests, } \\
\text { Lemna minor }\end{array}$ & 221 & ISO 20079 & - \\
\hline \multicolumn{5}{|c|}{ Microorganisms } \\
\hline 14. & $\begin{array}{l}\text { Inhibition of oxygen consumption } \\
\text { by active sludge }\end{array}$ & 209 & ISO 8192 & $\begin{array}{l}\text { Microtox (Vibrio fischeri, Photobacterium } \\
\text { phosfophoreum) }\end{array}$ \\
\hline 15. & $\begin{array}{l}\text { Inhibition of nitrification of active } \\
\text { sludge microorganisms }\end{array}$ & - & ISO 9509 & $\begin{array}{l}\text { Test ECHA (Bacilus stearithermophilis) } \\
\text { Toxi-chromotest PAD, MetPAD, }\end{array}$ \\
\hline 16. & $\begin{array}{l}\text { Bioluminescent bacteria } \\
\text { inhibition test, Vibrio fischeri }\end{array}$ & - & $\begin{array}{l}\text { ISO } \\
11348-1,2,3\end{array}$ & $\begin{array}{l}\text { Chromotest, Toxi-chromotest (Escherichia } \\
\text { coli) }\end{array}$ \\
\hline 17. & $\begin{array}{l}\text { Bacteria growth inhibition test, } \\
\text { Pseudomonas aeruginosa }\end{array}$ & - & ISO 10712 & $\begin{array}{l}\text { Muta- ChromoPlate (Salmonella } \\
\text { typhimurium mutant) } \\
\text { MARA test (with } 11 \text { bacteria sp.) }\end{array}$ \\
\hline
\end{tabular}

Table 2. OECD / ISO / EPA and microbiotests methods generally used in UE for aquatic toxicity assessment of chemicals / environmental samples

\section{Laboratory experiments}

\subsection{Chemicals}

To assess the ecotoxicity and risk assessment of cationic and amphoteric surfactants, seven compounds were selected:

- cationic surfactants: dialkylhydroxyethyl ammonium methasulphate (TEAQ) C16-C18, commercial name TETRANYL AT 7590, CAS: 93334-15-7, 1.017 meq/g, Kao Corporation S.A; Cetylpyridinium bromide, CAS: 140-72-7; benzenthonium chloride monohydrate, commercial name HYAMINE 1622, CAS: 121-54-0,>96\% (Sigma-Aldrich).tow softeners base on TEA esterquats CAS 91995-81-2 and CAS 157905-74-3;

- amphoteric surfactants: laurilamidopropylbetaine / cocamidopropylbetaine - CAPB, commercial name AMFODAC LB, CAS: 4292-10-8, 34.6 \%, Sasol Italy S.P.A; and a commercial toilet detergent base on CAPB.

The ecotoxicity experiments were performed for individual surfactants, mixtures of the cationic with amphoteric surfactants and different products base on cationic and amphoteric compounds, in order to obtain a complex response of the surfactants toxicity. 


\section{Aquatic toxicity of surfactants}

\section{$\mathrm{L}(\mathrm{E}) \mathrm{C} 50 / \mathrm{NOEC}[\mathrm{mg} / \mathrm{L}]$}

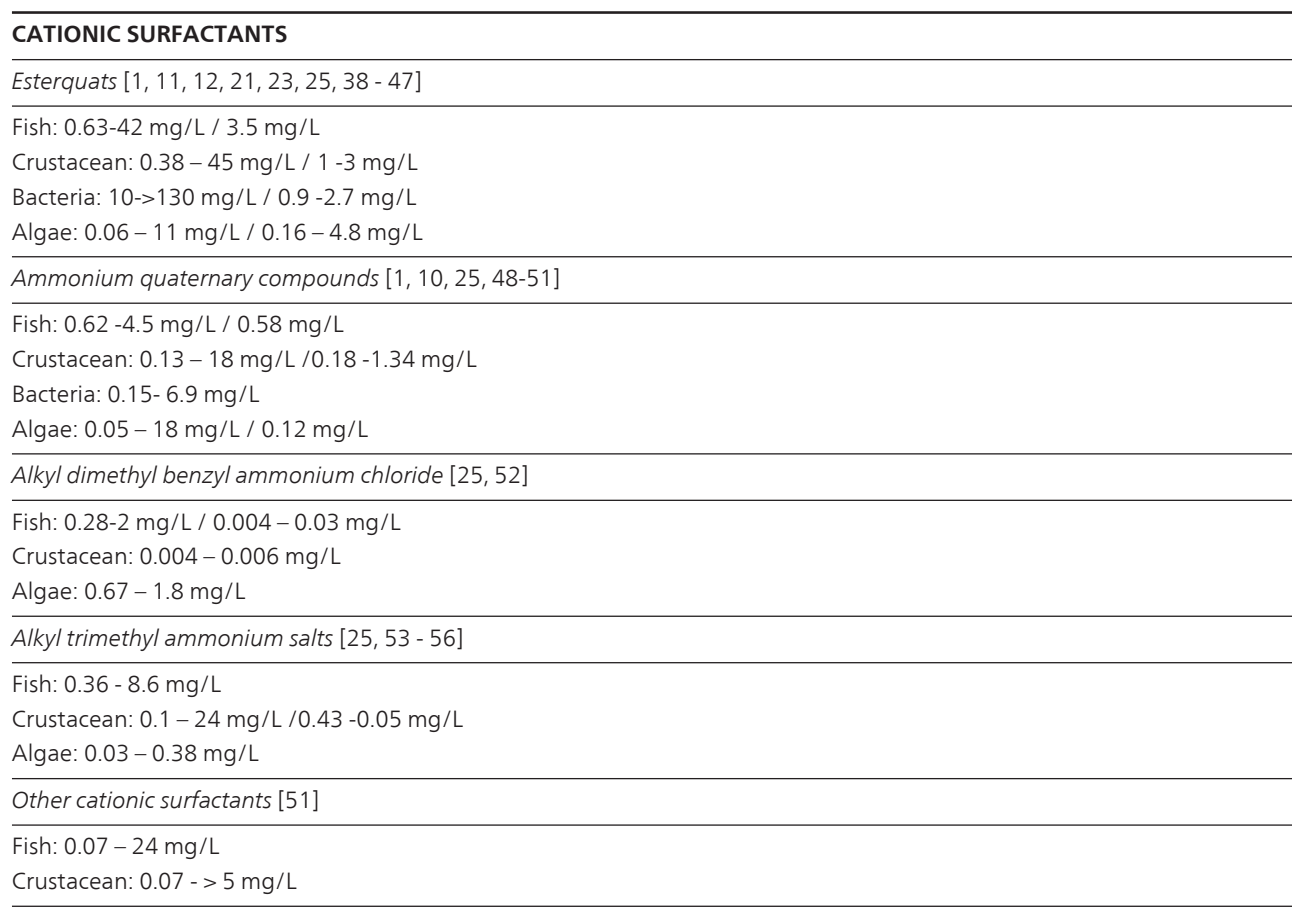

\section{AMPHOTERIC SURFACTANTS}

Imidazoline derivatives [1]

Fish: $8.1 \mathrm{mg} / \mathrm{L}$

Crustacean: 41 - $520 \mathrm{mg} / \mathrm{L}$

Bacteria: $22-900 \mathrm{mg} / \mathrm{L}$

Coco alkyl derivatives $[10,25,26,30,31,57,58]$

Fish: 2 - $31 \mathrm{mg} / \mathrm{L} / 0.16-1.7 \mathrm{mg} / \mathrm{L}$

Crustacean: 2.15 - $48 \mathrm{mg} / \mathrm{L} / 0.9-1.6 \mathrm{mg} / \mathrm{L}$

Bacteria: 5.2 - $78 \mathrm{mg} / \mathrm{L}$

Algae: $0.09-48 \mathrm{mg} / \mathrm{L} / 0.09-10 \mathrm{mg} / \mathrm{L}$

Table 3. Aquatic toxicity data for cationic and amphoteric surfactants

\subsection{Analytical control}

The methods used for qualitative and quantitative analytical control of surfactants are spectrometric, titrimetric and chromatographic [16, 59-64].

In our studies, the analytical control of cationic and amphoteric surfactants in the synthetic solutions used in ecotoxicity tests and also in the environmental samples (waste water and surface water) was performed according to the standard methods specified in Annex II of 
Detergents Regulation (spectrometric methods: DIN/EN 38409/1989-20 for cationic surfactants and Orange II method - Boiteux 1984 for amphoteric surfactants). The performance parameters are shown in Table 4 . According to other scientific studies [2,65], our results were comparable.

\begin{tabular}{|c|c|c|}
\hline \multirow{2}{*}{$\begin{array}{c}\text { Performance parameters of } \\
\text { the methods }\end{array}$} & $\begin{array}{l}\text { DIN 38409:1989, part } 20 \\
\text { Cationic surfactants }\end{array}$ & $\begin{array}{l}\text { Boiteux } 1984 \text { method, } \\
\text { Amphoteric surfactants }\end{array}$ \\
\hline & Hyamine 1622 (99.99\%) & Cocamidopropylbetaine (34.6\%) \\
\hline Wavelength & $628 \mathrm{~nm}$ & $485 \mathrm{~nm}$ \\
\hline Accuracy & $96.8 \%$ & $99 \%$ \\
\hline Fidelity [CV (RSD)] & $6.508 \%$ & $3.392 \%$ \\
\hline Repeatability (r) & $0.088 \mathrm{mg} / \mathrm{L}$ & $0.1128 \mathrm{mg} / \mathrm{L}$ \\
\hline Intern reproducibility $\left(R_{L}\right)$ & $0.0115 \mathrm{mg} / \mathrm{L}$ & $0.5161 \mathrm{mg} / \mathrm{L}$ \\
\hline Calibration curve equation & $x=6.9108 y-0.0069$ & $x=5.7837 y-0.0925$ \\
\hline Detection limits (LoD) & $0.003 \mathrm{mg} / \mathrm{L}$ & $0.002 \mathrm{mg} / \mathrm{L}$ \\
\hline Quantification limits (LoQ) & $0.035 \mathrm{mg} / \mathrm{L}$ & $0.032 \mathrm{mg} / \mathrm{L}$ \\
\hline Concentrations domain & $0.003-4 \mathrm{mg} / \mathrm{L}$ & $0.002-2 \mathrm{mg} / \mathrm{L}$ \\
\hline Recuperation & $80 \%-110 \%$ & $80 \%-110 \%$ \\
\hline Interferences & $\begin{array}{l}\text { Small concentrations of anionic } \\
\text { surfactants. This interference may be } \\
\text { eliminated through the use of the ions } \\
\text { exchange resins column. }\end{array}$ & $\begin{array}{l}\text { Small concentration of cationic and anionic } \\
\text { surfactants; this interference could be } \\
\text { remove by pH adjustment at alkaline values } \\
\text { or the use of the ions exchange resins } \\
\text { column. }\end{array}$ \\
\hline
\end{tabular}

Table 4. Methods performance parameters for quantitative determination of cationic and amphoteric surfactants

Detection limits of spectrometric methods are $0.003 \mathrm{mg} / \mathrm{L}$ for cationic surfactants and 0.002 $\mathrm{mg} / \mathrm{L}$ for amphoteric surfactants. The methods interferences are determined by the presence of other types of surfactants (anionic, cationic) and/or other organic substances, which react with the surfactant or with the color reagent to form stable compounds. These problems can be eliminated by using of ion exchange resins to separate the target surfactants.

Methods selectivity was ensured by using of standard curves performed for the main studied substances. For the selective detection of cationic compounds in environmental samples is recommended the use of standard HPLC techniques.

\section{Biodegradability assessment}

A significant request of Detergents Regulation is that each producer / distributor must to attest ultimate aerobic biodegradability of surfactants used in detergents. Our experiments target 
was to assess the primary and ultimate biodegradability for 2 surfactant raw materials (cationic - ammonium quaternary compounds and amphoteric - alkyl betaines), their mixture and 2 commercial cleaning products based on this type of surfactant.

For the compliance of the first criterion of aquatic risk assessment (biodegradability), was used OECD methodology specified in Annex III of Detergents Regulation (OECD 303A - similar with ISO 11733) -Simulation Test - Aerobic Sewage Treatment for primary biodegradability $[3,66]$; OECD 301A (similar with ISO 7827) - DOC Die - Away Test [67] and OECD 301D (similar with ISO 10707) - Closed Bottle Test [68])

\subsection{Primary biodegradability}

OECD confirmatory test for primary biodegradability assessment of surfactants describes a small activated sludge plant in continued flow (Figure 4), consisting in a vessel for synthetic sewage, an aeration vessel, a settling vessel, air-lift pumps to recycle the activated sludge and vessel for collecting the treated effluent. The degradation test was performed at $19-24^{\circ} \mathrm{C}$ and the duration of experiments was about 60 days. The monitored parameters of experimental equipment were the surfactants concentrations and chemical oxygen demand (COD) in influents and effluents, the content of dry mater in the activated sludge and oxygen concentration from aeration tank vessel.

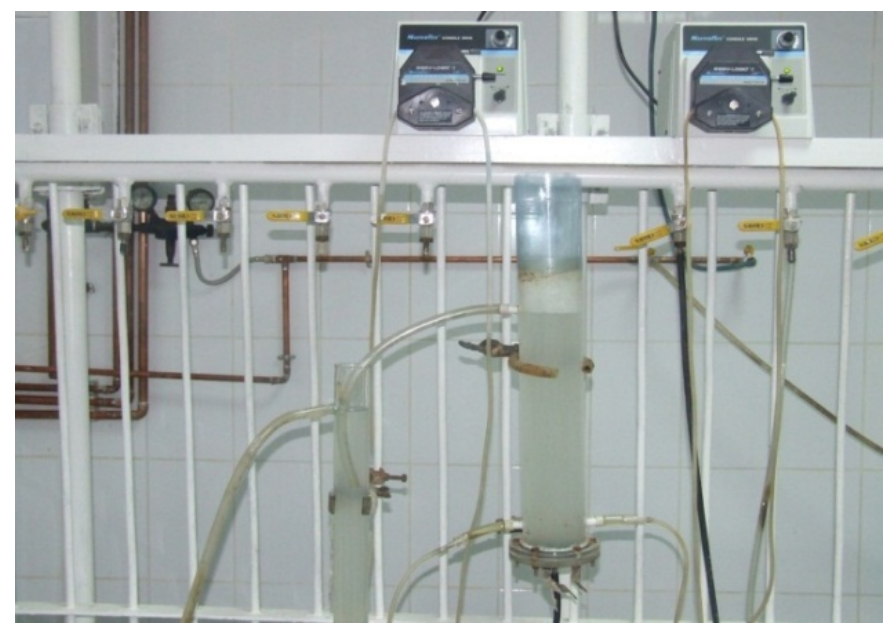

Figure 4. Laboratory simulation of aerobic sewage treatment

The efficiency of the biodegradation process (COD removal) and the percentage of biodegradability (surfactants degradation) were calculated (Table 5). Surfactants biodegradability was calculated as an arithmetic mean of daily removal efficiency values of surfactants, obtained in effective biodegradation period, during which degradation has been regular and the operation of the equipment trouble-free (Figure 5). 


\begin{tabular}{|c|c|c|c|c|c|c|}
\hline Result type & $\begin{array}{c}\text { Tetranyl AT } \\
7590\end{array}$ & $\begin{array}{l}\text { Hyamine } \\
1622\end{array}$ & $C A P B$ & $\begin{array}{l}\text { Hyamine } 1622 \\
+ \text { CAPB }\end{array}$ & $\begin{array}{l}\text { Tetranyl AT } \\
7590+\text { CAPB }\end{array}$ & $\begin{array}{c}\text { Cetylpyridinium } \\
\text { bromide }\end{array}$ \\
\hline Test time (days) & & 36 & & & 0 & 36 \\
\hline Lag time (days) & & 10 & & & 2 & 10 \\
\hline $\begin{array}{l}\text { Effective biodegradation time } \\
\text { (days) }\end{array}$ & & 26 & & & 8 & 26 \\
\hline COD removal (\%) & \multicolumn{2}{|c|}{$70-89$} & 90 & 61 & 68 & 50 \\
\hline Cationic surfactant removal (\%) & 90 & 84 & - & - & - & $77-80$ \\
\hline $\begin{array}{l}\text { Amphoteric surfactant removal } \\
(\%)\end{array}$ & - & - & 99 & - & - & - \\
\hline $\begin{array}{l}\text { Total surfactants removal } \\
\text { (cationic + amphoteric) \%) }\end{array}$ & - & - & - & 80 & 90 & - \\
\hline Biodegradation (\%) & 91 & 84 & 97 & 90.7 & 97.6 & 80 \\
\hline
\end{tabular}

Table 5. Primary biodegradability of cationic and amphoteric surfactants

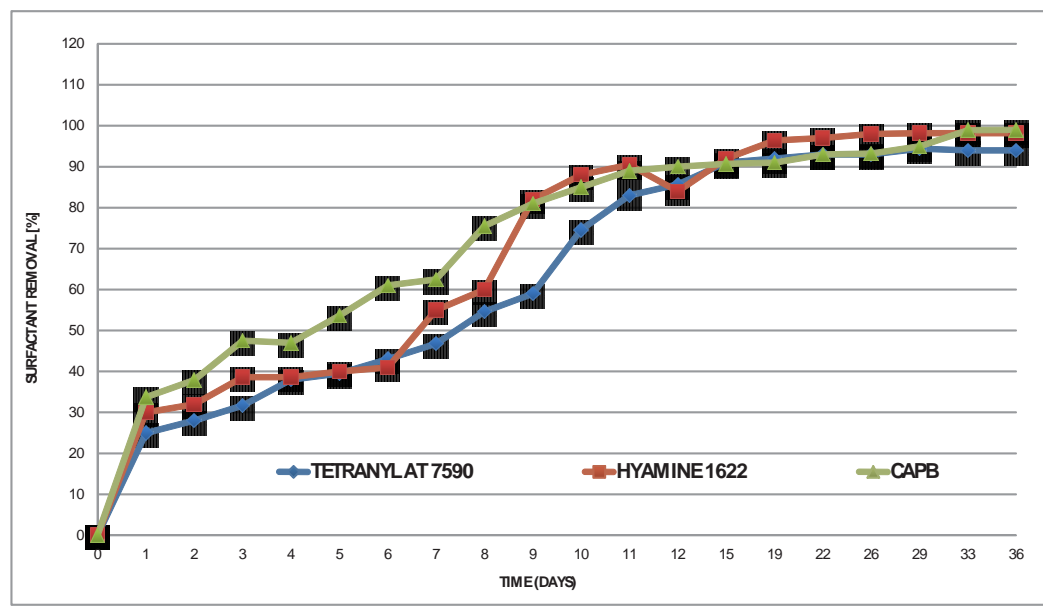

Figure 5. Primary biodegradability - individual surfactants removal

Considering the OECD confirmatory test, the level of primary biodegradability must be at least $80 \%$ in 21 days after the biological system initiation, for that the surfactant can be accepted as biodegradable and used as basic compound in commercial products. Our results showed a primary biodegradation $>90 \%$ for the cationic surfactant (TETRANYL AT 7590), amphoteric surfactant (cocamidopropylbetaine) and mixtures (cationic + amphoteric), while for the HYAMINE 1622 (cationic standard) and commercial product (cationic biocide - cetylpyridinium bromide) the primary biodegradation is in limit of $80-84 \%$. 
According to biodegradability criteria imposed by Regulation 648/2004, all the testing surfactants meet the conditions; the levels of biodegradation obtained were $\geq 80 \%$ [69-71]. The results were in line with the literature data on primary biodegradability of cationic and amphoteric surfactants (Table 5) [11, 22, 27].

\subsection{Ultimate biodegradability}

OECD 301A (ISO 7827) - DOC Die - Away Test, allowed the ultimate biodegradability assessment of substances / chemical products, in a given concentration, in a synthetic media, subject to aerobe microorganisms. According to this method, cleaning product - toilet detergent solution based on amphoteric surfactant was tested. The concentrations of DOC and amphoteric surfactant were determined and the percentage DOC / surfactant removal were calculated (Table 6). The obtained remove percentages were graphically represented in Figure 6.

\begin{tabular}{lc}
\hline \multicolumn{1}{c}{ Result type } & Toilet detergent based on CAPB \\
\hline Experimental period (days) & 30 \\
\hline Maximum level of biodegradation (\%) & $91.43-$ removal of DOC \\
\hline Lag time (days) & 3 \\
\hline Biodegradation time (days) & 20 \\
\hline Amphoteric surfactant removal after 30 days (\%) & 72.85 \\
\hline Abiotic removal for DOC (\%) & 14 \\
\hline
\end{tabular}

Table 6. Ultimate biodegradability test results for an amphoteric product

Biodegradability test performed considers that a substance is biodegradable if no significant abiotic removal was observed, the curves shows a typical form with lag and degradation phase and the DOC removal can be attributed to the biodegradation process of the substance. In conclusion, our results considered that:

- The total removal of dissolved organic carbon (DOC \%) for the testing product (toilet cleaner based amphoteric surfactant - cocamidopropyl betaine) is $~ 92 \%$, with an abiotic elimination of $14 \%$;

- Effective biodegradation (the interval between the end of the lag time and the necessary time for the $90 \%$ DOC removal) is 20 days;

- Toilet cleaner commercial product base on amphoteric surfactant is biodegradable.

In line with the literature we estimated that $91.43 \%$ of ultimate biodegradability obtained for cocamidopropilbetaine is within the range of $57 \%-100 \%$ specified for the same method or different methods recommended by OECD for ultimate biodegradability testing of amphoteric surfactants (see Table 1). 


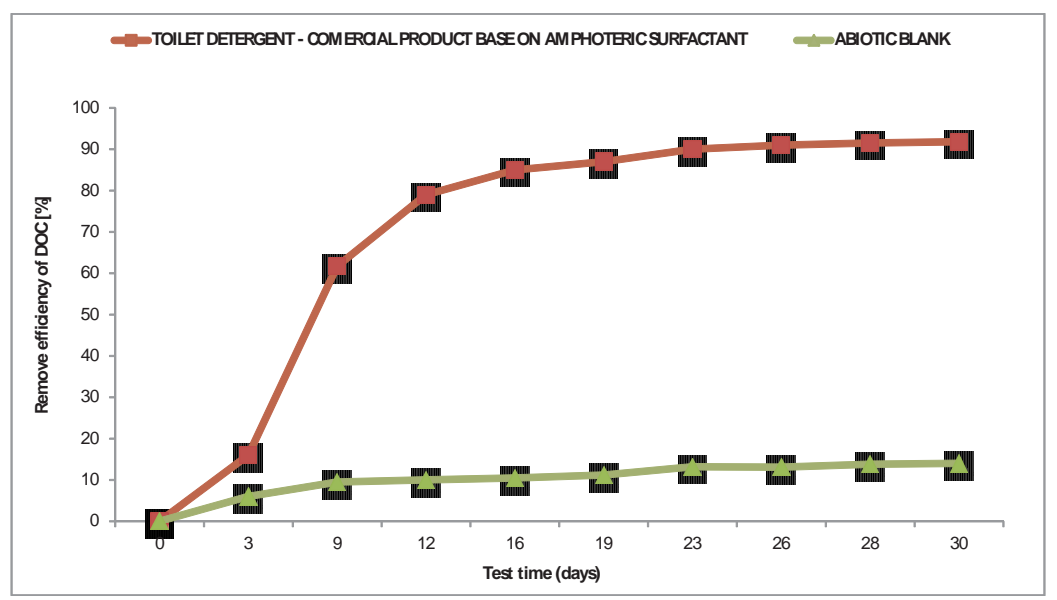

Figure 6. Ultimate biodegradability efficiency chart for the amphoteric product

OECD 301D (ISO 10707) - Closed Bottle Test, allows the ultimate biodegradability assessment of organic compounds present in a given concentration, subject to aerobe microorganisms, through biochemical oxygen demand (BOD) analyze. The test substance solution ( which is the single source of carbon and energy), is inoculated with a little number of mixed aerobe microorganisms, incubated at dark, in closed and well filled recipients. The biodegradability indicator is dissolved oxygen concentration, parameter that is measured at regular intervals in a standard 28-days period. At the end of each time interval was calculated the oxygen removal, as a difference between the oxygen concentration of test substance and the control (Table 7). A biodegradability curve with the testing time on abscises and the biodegradability mean percentages on ordinate were plotted, for each time moment (Figure 7).

According with OECD 301D methodologies, an organic compound is biodegradable, when the biodegradation percentage is $\geq 60 \%$, after 28 days of testing.

The experimental results obtained, have shown that the studied cationic surfactants and the cleaning product - laundry softeners are finally biodegraded with $>70 \%$. Considering other biodegradability studies for similar cationic compounds, our experimental results for TETRANYL AT 7590 (78\%) and fabric softeners based on it (77\%, 85\%) can be compared with the ultimate biodegradability values of esterquat and diesterquat cationic compounds, ranging from $>60 \%-79 \%$ using the same method and $75 \%-92 \%$ using other OECD methods.

Regarding the ultimate biodegradability for the benzenthonium chloride, the literature, specify a range of $0-81 \%$ biodegradability using various OECD methods and $>5 \%$ using the OECD 301D method (Table 1). Therefore, the percentage of biodegradation - $67 \%$ after 28 days, obtained in our laboratory experiments can be correlated with existing data. 


\begin{tabular}{lccccc}
\hline \multicolumn{1}{c}{ Result type } & Tetranyl AT 7590 & Hyamine 1622 & $\begin{array}{c}\text { Laundry } \\
\text { balm I }\end{array}$ & $\begin{array}{c}\text { Laundry } \\
\text { balm II }\end{array}$ & Aniline \\
\hline Test time (days) & $7-10$ & $7-10$ & $7-10$ & 7 & 7 \\
\hline Lag time (days) & 14 & 14 & 14 & 21 & $12-14$ \\
\hline Effective biodegradation time (days) & 83.86 & 73.15 & 84.70 & 99.16 & - \\
\hline Remove of surfactants (\%) & 78.37 & 67.23 & 77.34 & 85.80 & 95.23 \\
\hline Biodegradability after 28 days (\%) & & & & & 28 \\
\hline
\end{tabular}

Table 7. Ultimate biodegradability results for cationic surfactants

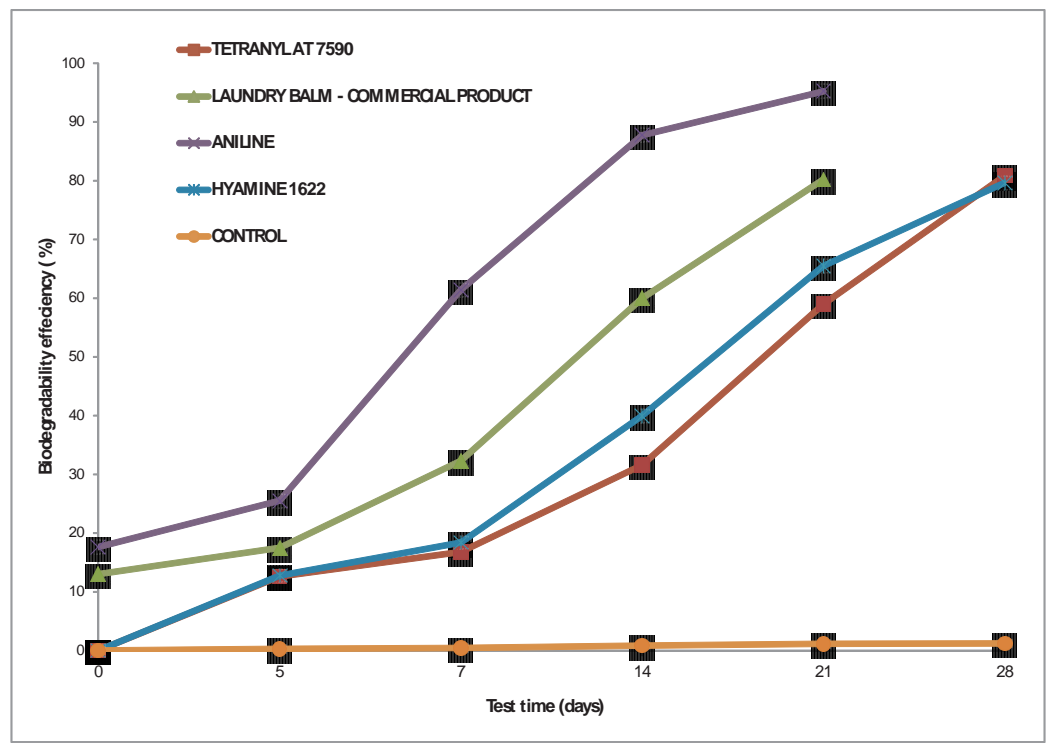

Figure 7. Ultimate biodegradation of cationic surfactants

\section{Acute toxicity assessment}

Considering the second criterion of ecotoxicological characterization / aquatic risk assessment, this chapter part aimed to evaluate the aquatic toxicity of surfactants on the most representative species of the Romanian surface waters. In accordance with the Europeans norms concerning surfactants and chemicals and OECD/ ISO/ ASTM testing methodology [72 - 75], the present study want to highlight the direct and indirect effects of cationic and amphoteric surfactants (benzenthonium chloride, dialkylhydroxyethyl ammonium methasulphate and cocamidopropylbetaine). 


\subsection{Direct toxicity}

To evaluate the acute toxic effects of surfactants have conducted laboratory experiments in static and semi-static conditions, with distinct organisms from aquatic food chain, as followed:

- Acute lethal toxicity test with freshwater fish(1 year juvenile carp - Cyprinus carpio sp.) performed for determination of the mean Lethal Concentration which induce the death of half from the test organisms (fish) - LC50, according with OECD 203. The fish are exposed to testing surfactants, in different concentrations $(0.5 \mathrm{mg} / \mathrm{L}-100 \mathrm{mg} / \mathrm{L})$, for $96 \mathrm{~h}$. The effect (mortality) is registered at each $24 \mathrm{~h}$ and the concentration which kills $50 \%$ of fish at the final of test period is calculated.

- Acute toxicity test with water fleas Daphnia magna Status (Cladocera crustacea ) performed for determination of Effective Concentration (EC50) which have a 50\% impact on test organisms using Daphtoxkit FTM magna microbiotest, in accordance with OECD 202. The $24 \mathrm{~h}$ to $48 \mathrm{~h}$ EC50 bioassays was performed in disposable multiwall test plates starting from neonates of Daphnia magna, uniform in size and age, hatched from ephippia and exposed to different concentration of surfactant $(0.05 \mathrm{mg} / \mathrm{L}-50 \mathrm{mg} / \mathrm{L})$ at $20 \mathrm{oC}$, in darkness.

- Green algae growth inhibition test performed for determination of inhibitory / stimulatory concentration (EC50) with 50\% effect on algae - Selenastrum capricornutum (Raphidocelis subcapitata or Pseudokirchneriella subcapitata) in accordance with OECD 201 and ISO/DIS 8692. This toxicity test was performed with Algaltoxkit FTM microbiotest which suppose the measurement of the algal growth (at $670 \mathrm{~nm}$ ) in the long cells after $24 \mathrm{~h}, 48 \mathrm{~h}$ and $72 \mathrm{~h}$ incubation $(23 \mathrm{oC})$ and calculation of inhibitory concentration in the test concentrations $(0.05$ $-10 \mathrm{mg} / \mathrm{L}$ surfactant) versus the growth in the control.

- Acute toxicity test with luminescent bacteria to estimate the toxic effect of surfactants on Vibrio fischeri sp, using the "BioFixLumi" equipment which respects criteria of DIN EN ISO 11348-3. The principle of method is: marine bacteria release luminescence as a metabolic product which can be affected by chemicals. With help of "BioFixLumi" system was measured the light intensity produced by bacteria, before and after 15 or 30 minute of incubation, in the presence of pollutant and against the control. The intensity difference between sample and control was associated with the effect of pollutants on microorganisms: inhibition or stimulation. The test concentrations of cationic surfactants were in the interval $0.05-10 \mathrm{mg} / \mathrm{L}$ and for amphoteric surfactant $3-80 \mathrm{mg} / \mathrm{L}$.

- Microbial Assay for Risk Assessment (MARA) test- is a multi-species toxicity test based on responses of 11 microorganisms (prokaryote and eukaryote bacteria) to toxic compounds. The microbial growth is determined by a redox dye reduction which induces insoluble reaction products (red) which precipitate and form a pellet in the plate. The plate is scanned and the image is analyzed by MARA software for toxicity determination. The test was performed for $0.021-5 \mathrm{mg} / \mathrm{L}$ cationic standard solutions and $0.041-10 \mathrm{mg} / \mathrm{L}$ cationic raw material solutions.

The levels of toxicity class are drawn in accordance with international regulations EPA [72] and national legislative program (H.G. 1408/2008)[76], as followed: Highly toxic $-\mathrm{LC}_{50} / \mathrm{EC}_{50}<1 \mathrm{mg} /$ $\mathrm{L}$; Toxic - 1mg/L $<\mathrm{LC}_{50} / \mathrm{EC}_{50} \leq 10 \mathrm{mg} / \mathrm{L}$; Harmful / hazardous for aquatic environment - 10 $\mathrm{mg} / \mathrm{L}<\mathrm{LC}_{50} / \mathrm{EC}_{50} \leq 100 \mathrm{mg} / \mathrm{L}$; Very low toxic, non-toxic $-\mathrm{LC}_{50} / \mathrm{EC}_{50}>100 \mathrm{mg} / \mathrm{L}$. 
The final results concerning the acute effects of individual surfactants are summarized in the Table 8 and Figure 8.

\begin{tabular}{|c|c|c|c|c|c|c|c|c|c|}
\hline \multirow[b]{2}{*}{ Test organisms } & \multicolumn{3}{|c|}{ HYAMINE 1622} & \multicolumn{3}{|c|}{ TETRANYL AT 7590} & \multicolumn{3}{|c|}{ CAPB } \\
\hline & $\begin{array}{c}\mathrm{LC}_{50} / \mathrm{EC}_{50} \\
\mathrm{mg} / \mathrm{L}\end{array}$ & $\begin{array}{l}\text { NOEC } \\
\mathrm{mg} / \mathrm{L}\end{array}$ & $\begin{array}{l}\text { LOEC } \\
\mathrm{mg} / \mathrm{L}\end{array}$ & $\begin{array}{c}\mathrm{LC}_{50} / \mathrm{EC}_{50} \\
\mathrm{mg} / \mathrm{L}\end{array}$ & NOEC mg/L & $\begin{array}{l}\text { LOEC } \\
\mathrm{mg} / \mathrm{L}\end{array}$ & $\begin{array}{c}\mathrm{LC}_{50} / \mathrm{EC}_{50} \\
\mathrm{mg} / \mathrm{L}\end{array}$ & $\begin{array}{l}\text { NOEC } \\
\mathrm{mg} / \mathrm{L}\end{array}$ & $\begin{array}{l}\text { LOEC } \\
\mathrm{mg} / \mathrm{L}\end{array}$ \\
\hline Cyprinus carpio & $\begin{array}{c}4.57 \\
(1.94- \\
9.77)\end{array}$ & 0.5 & 1 & $\begin{array}{c}22.90 \\
(11.22-33.65)\end{array}$ & 2 & 7 & $\begin{array}{l}6.16 \\
(2.81- \\
11.74)\end{array}$ & 1 & 2 \\
\hline Daphnia magna & $\begin{array}{c}0.39 \\
(0.15-0.48)\end{array}$ & 0.05 & 0.1 & $\begin{array}{c}4.78 \\
(3.05-6.13)\end{array}$ & 0.05 & 0.1 & $\begin{array}{l}9.54 \\
(7.25- \\
11.08)\end{array}$ & 1 & 5 \\
\hline $\begin{array}{l}\text { Selenastrum } \\
\text { capricornutum }\end{array}$ & $\begin{array}{c}0.56 \\
(0.12 \\
-1.25)\end{array}$ & 0.05 & 0.1 & $\begin{array}{c}3.48 \\
(1.67-5.12)\end{array}$ & 0.05 & 0.1 & $\begin{array}{l}5.55 \\
(3.59- \\
7.21)\end{array}$ & 0.1 & 0.5 \\
\hline Vibrio fischeri & 1.2 & 0.3 & - & 2.89 & 0.4 & - & $>100$ & 0.4 & - \\
\hline Microbial toxicity & 1.1 & - & 0.02 & 1.6 & - & 0.04 & - & - & - \\
\hline TOXICITY CLASS & \multicolumn{3}{|c|}{$\begin{array}{c}\text { HIGHLY TOXIC (for crustacean } \\
\text { and algae) / TOXIC (for fish } \\
\text { and bacteria) }\end{array}$} & \multicolumn{3}{|c|}{$\begin{array}{c}\text { TOXIC (for crustacean, algae, and } \\
\text { bacteria) / HARMFUL/HAZARDOUS } \\
\text { (for fish) }\end{array}$} & \multicolumn{3}{|c|}{$\begin{array}{c}\text { NON-TOXIC (for luminescent } \\
\text { bacteria) / TOXIC (for fish, } \\
\text { crustacean and algae) }\end{array}$} \\
\hline $\begin{array}{l}\text { Literature toxicity } \\
\text { data according to } \\
\text { Table } 3\end{array}$ & \multicolumn{6}{|c|}{$\begin{array}{c}\text { Fish: } \mathrm{LC}_{50}-0.28-42 \mathrm{mg} / \mathrm{L} ; \mathrm{NOEC}: 0.004-3.5 \mathrm{mg} / \mathrm{L} \\
\text { Crustacean: } \mathrm{EC}_{50}-0.0059-78 \mathrm{mg} / \mathrm{L} ; \mathrm{NOEC}-0.0041-3 \mathrm{mg} / \mathrm{L} \\
\text { Algae: } \mathrm{EC}_{50}-0.09-11 \mathrm{mg} / \mathrm{L} ; \mathrm{NOEC}-0.16-4.8 \mathrm{mg} / \mathrm{L} \\
\text { Bacteria: } \mathrm{EC}_{50}-0.5->130 \mathrm{mg} / \mathrm{L} .\end{array}$} & \multicolumn{3}{|c|}{$\begin{array}{c}\text { Fish: } \mathrm{LC}_{50}-2-31 \mathrm{mg} / \mathrm{L} ; \mathrm{NOEC} \\
\quad 0.16-1.7 \mathrm{mg} / \mathrm{L} \\
\text { Crustacean: } \mathrm{EC}_{50}-2.15->200 \\
\mathrm{mg} / \mathrm{L} ; \mathrm{NOEC}-0.9-1.6 \mathrm{mg} / \mathrm{L} \\
\text { Algae: } \mathrm{EC}_{50}-0.55-48 \mathrm{mg} / \mathrm{L} ; \\
\quad \mathrm{NOEC}-0.09-10 \mathrm{mg} / \mathrm{L} \\
\text { Bacteria: } \mathrm{EC}_{50}-5.2-900 \mathrm{mg} / \mathrm{L} .\end{array}$} \\
\hline
\end{tabular}

Table 8. Experimental toxicity data of studied surfactants

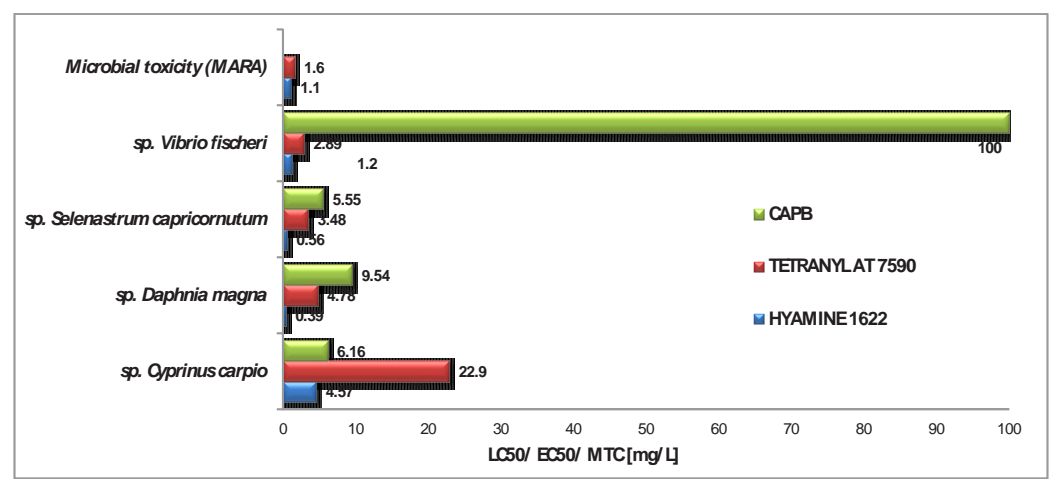

Figure 8. Toxicity quantum of cationic and amphoteric surfactants on aquatic organisms 
Compared with other ecotoxicity studies (Table 3), the selected cationic surfactant Hyamine 1622 (benzenthonium chloride) with aromatic chains have a great toxic effect, while the TETRANYL AT 7590 (dialkylhydroxyethyl ammonium metasulphate) with linear alkyl chains have a toxic / harmful effect on aquatic organisms, indicating that toxicity was influenced by the chemical structure, which is also indicated in the literature [18, 32].

The highly toxic effect of benzenthonium chloride is caused by his biocide proprieties which damage the fish, algae, crustacean and bacteria, whit a great environmental risk potential in the most detrimental scenario. In case of cationic raw material (TETRANYL AT 7590), the acute toxicity effects on the testing organisms were smaller. This effect is due to the presence of the slight ester ties which are easily biodegraded by microorganisms and thus the substance biodisponibility to the target organisms is more reduced.

Because of intense foaming, the amphoteric surfactant, cause the exchange gases blocking in the gills and cell membranes, inducing the mortality / immobilization and growth inhibition in fish, water flea and algae. No toxic effect on bacteria was observed.

In accordance with Table 8 and Globally Harmonized System for Classification and Labelling of Chemicals (GHS) [77], we estimated that the cationic surfactant - benzenthonium chloride is classified as "Acute toxic, first class" because caused a highly toxic effect on the crustacean and algae at $<1 \mathrm{mg} / \mathrm{L}$. The cationic (diakylhydroxyethyl ammonium metasulphate) and amphorteric (cocamidpropylbetaine) surfactants were classified as "Acute toxic, second class" due to their toxic / harmful effects for the majority of test organisms at 1-10 mg/L.

Our toxicity results (LC50/ EC50 and NOEC) are in line with other toxicity values for this type of pollutants, and therefore we consider being scientifically relevant and can be used in aquatic risk assessment.

\subsection{Indirect toxicity}

To meet the requirements concerning the complementary aquatic risk of surfactants, toxicity bioassays (with fish, crustaceans, algae and bacteria) of effluents from biodegradation experiments were performed [5].

The toxicity evaluation of cationic surfactants effluents (benzenthonium chloride and dialkylhydroxyethyl ammonium metasulphte) resulted after ultimate biodegradability tests was performed according to "Toxicity Classification System for the discharged effluents into the aquatic environment" [37]. The principle is to determine and quantify the acute toxicity of effluents using a microbiotests battery. Effluent toxicity assessment is based on two types of values: an acute toxic value of effluent - transformed in toxicity units $\mathrm{TU}=\left[1 / \mathrm{L}(\mathrm{E}) \mathrm{C}_{50}\right] \times 100$, that can fit in one of the 5 classes of toxicity and value of the weight score for each toxicity class.

The tests showed that biodegradation effluents have a toxic impact on target organisms and the level of toxicity varies depending of species. The algae and bacteria were the most sensible, which can be correlated with the effect caused by the original compounds of these species.

In Table 9 are presented the measured effects of the cationic biodegradation effluents and their toxicity classification. Experimental results have highlighted that benzenthoniu chloride 
(Hyamine 1622) effluent was acutely toxic for all target organisms, while the Teranyl AT 7590 effluent determined a low toxic effect, and also, a greater influence on the algae and bacteria for both tested substances.

\begin{tabular}{|c|c|c|c|}
\hline \multirow[b]{2}{*}{ Organisms } & \multicolumn{2}{|c|}{$\begin{array}{c}\text { Toxicity Unit (TU) } \\
\text { calculated for each } \mathrm{LC}_{50} / \mathrm{EC}_{50}\end{array}$} & \multirow{2}{*}{$\begin{array}{c}\text { Classification System of } \\
\text { discharged effluents in to } \\
\text { natural aquatic } \\
\text { environmental [32] }\end{array}$} \\
\hline & $\begin{array}{l}\text { Biodegradation effluent of } \\
\text { HYAMINE } 1622 \text { ( } 0.9 \mathrm{mg} / \mathrm{L})\end{array}$ & $\begin{array}{l}\text { Biodegradation effluent of } \\
\text { TETRANYL AT } 7590 \\
(0.25 \mathrm{mg} / \mathrm{L})\end{array}$ & \\
\hline Cyprinus carpio & $\begin{array}{c}0 \\
\text { weight score } 0\end{array}$ & $\begin{array}{c}0 \\
\text { weight score } 0\end{array}$ & $\mathrm{TU}<0.4$ \\
\hline Daphnia magna & $\begin{array}{c}2 \\
\text { weight score } 2\end{array}$ & $\begin{array}{c}0 \\
\text { weight score } 0\end{array}$ & $\begin{array}{c}0.4<T U<1 \\
\text { Class II - small acute toxicity }\end{array}$ \\
\hline Selenastrum capricornutum & $\begin{array}{c}3.32 \\
\text { weight score } 2\end{array}$ & $\begin{array}{c}1.2 \\
\text { weight score } 2\end{array}$ & $\begin{array}{c}1<\mathrm{TU}<10 \\
\text { Class III - acute toxicity }\end{array}$ \\
\hline Vibrio fischeri & $\begin{array}{c}4.98 \\
\text { weight score } 2\end{array}$ & $\begin{array}{c}2.24 \\
\text { weight score } 2\end{array}$ & $\begin{array}{c}10<\mathrm{TU}<100 \\
\text { Class IV }- \text { high acute toxicity }\end{array}$ \\
\hline $\begin{array}{l}\text { TU for biotests battery / } \\
\text { Toxicity Class }\end{array}$ & $\begin{array}{c}2.57 \\
\text { Class III - acute toxicity } \\
\text { weight score } 2\end{array}$ & $\begin{array}{c}0.86 \\
\text { Class II - small acute toxicity } \\
\text { weight score } 1\end{array}$ & $\begin{array}{c}\text { Class } V \text { - very high acute } \\
\text { toxicity }\end{array}$ \\
\hline
\end{tabular}

Table 9. Toxicity classification of biodegradability effluents of the studied cationic surfactants

The toxic effects of surfactants biodegradation solutions, lead us to hypothesize of recalcitrant biodegradation metabolites occurrence with toxic effects potential on aquatic organisms, but their detection is not yet clarified. Other hypothesize is the persistence of testing surfactants, in case of benzenthonium chloride, for which was recorded the lowest ultimate biodegradability (67\%), also confirmed by literature data.

For in situ extrapolation (surface water), the experimental toxicity values obtained will be reduced considerably, concerning the rivers dilution (100 fold to 1000 fold). Toxicity behavior of the surfactants depends on physical - chemical factors ( $\mathrm{pH}$, temperature, oxygen, microbial charge, climate change, the presence of other chemicals, etc.) that can affect the bioavailability.

Another toxicity experiment was performed in order to reveal the toxic effects of the cationic surfactants used as base ingredient in commercial products (eg. biocide - algaecide). In this case was estimated the toxicological behavior of this compound mixed with other ingredients. An acute growth inhibition test with algae was performed for a biocide product containing $50 \%$ of alkylbenzyldimethyl ammonium chloride C12-C16 (CAS 68424-85-1). In mixture with other ingredients (eg. ethylene glycol $2 \%$ and water $48 \%$ ), cationic surfactants maintain his initial toxicity, but the level of effects depend of purpose of use and proportion of ingredients. According to international norms the product was highly toxic / very toxic to freshwater algae Selenastrum capricornutum, the estimated $\mathrm{CE}_{\mathrm{r} 50}$ value was $<1 \mathrm{mg} / \mathrm{L}$. 


\section{Aquatic risk assessment - Case study}

The aim of surfactants aquatic risk assessment methodology was to establish the maximum allowable cationic and amphoteric surfactants (HYAMINE 1622 CAS 121-54-00 and cocamidopropyl betaine CAS 4292-10-8) concentrations in surface water in order to avoid their negative impact on aquatic ecosystem and to assure the health of aquatic organisms in trophic chain.

The aquatic risk assessment involve the collection of literature data and laboratory testing results to estimate the predicted exposure concentrations of cationic and amphoteric surfactants in the water (PEC aquatic) and the no-effect concentration on organisms (PNEC aquatic). Comparison of these data allowed us to determine whether the studied substances have adverse effects in the aquatic environment, using the PEC / PNEC ratio, where the PEC value must be lower than the PNEC, so that the compounds not present risk to aquatic life. For individual substances PEC / PNEC must be $<1$, which indicates that there will not be necessary further researches to identify potentially risk.

Given the international methodologies, environmental risk studies [11, 52, 78-83] and the laboratory informations obtained in this work, the important steps of aquatic risk assessment strategy are presented in Figure 9.

In Table 10 and 11 are summarized the most important data of risk coefficients (PEC/PNEC ratio) for each studied surfactant class. We have selected several scenarios, considering the minimum and maximum of aquatic PEC values and the lowest acute $\left(\mathrm{LC}_{\mathrm{EC}} \mathrm{E}\right)$ and chronic (NOEC) toxicity values, identified in the relevant literature studies and from our studies. In order to obtain the PNEC values, we used the lowest toxicity values and different application factors recommended at international level for risk assessment (OECD, EC and ECETOC).

The risk coefficients calculated for the studied surfactants were different. In case of benzenthonium chloride (cationic surfactant class) from 15 scenarios of risk coefficients, the PEC/ PNEC rapport was $<1$ (Table 10), in the range of $2.56-512$. The results suggest that this compound and its class homologues could have negative impact on the aquatic environment. This conclusion is sustained by hypothesis of complementary effects concerning the persistence or recalcitrant metabolites occurrence. As a result of risk data analysis and taking into consideration that monitoring and control of cationic surfactants concentrations are not imposed within national and international regulations on surface water quality, we recommend the value of benzenthonium chloride $\leq 0.002 \mathrm{mg} / \mathrm{L}$ as maximum allowed concentration in surface water (MATC), so that aquatic ecosystem life is not affected.

The risk coefficients of the amphoteric surfactant (cocamidopropylbetaine) were $>1$ and 10 different scenarios were analyzed in range of $0.036-0.38$. In this case the studied amphoteric surfactant and its homologue class were safety for aquatic environment. Considering that amphoteric surfactants control and monitoring are not imposed, we estimate the value of 0.01 $\mathrm{mg} / \mathrm{L}$ cocamidopropylbetaine as maximum allowed concentration (MATC) in surface water. 


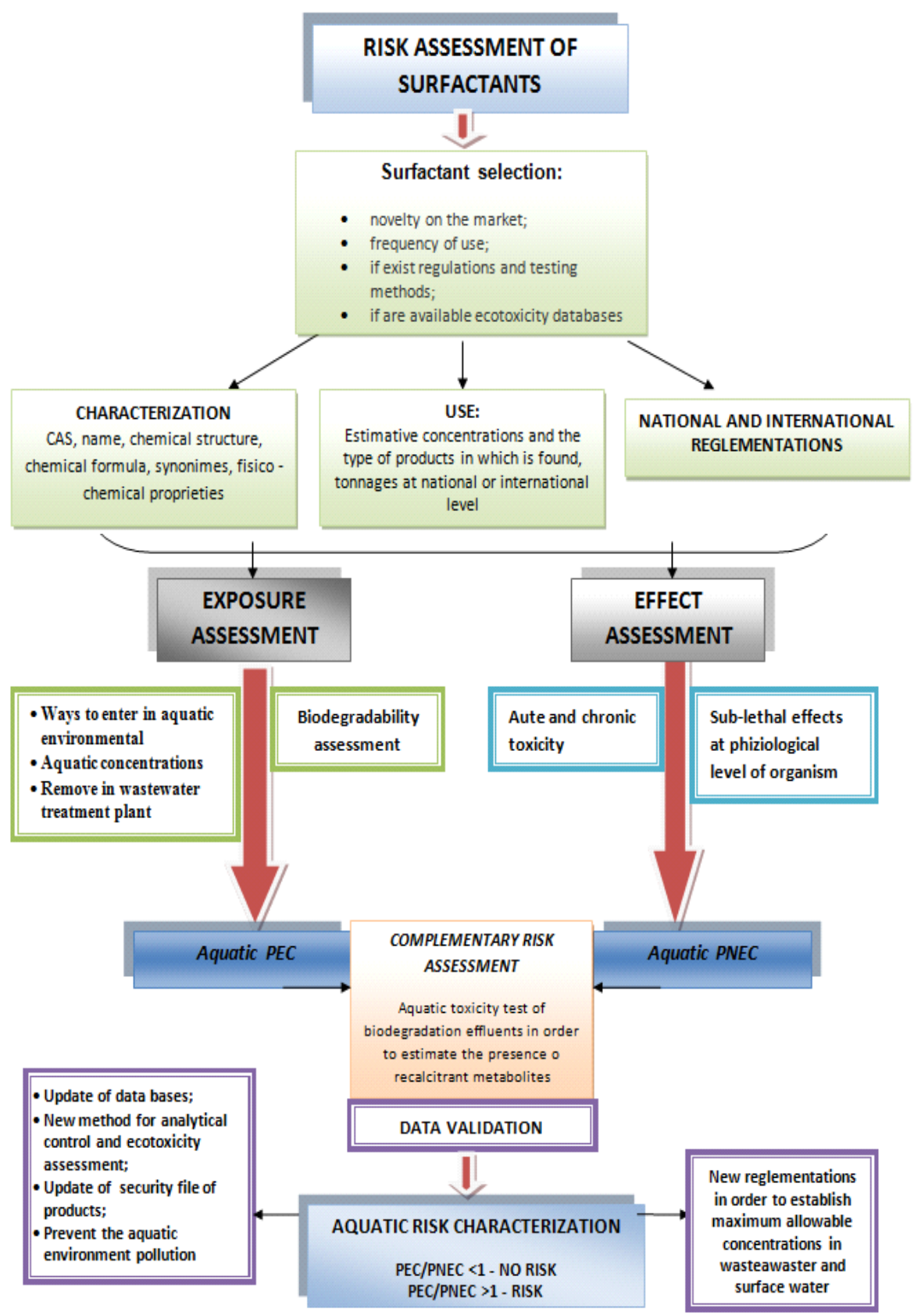

Figure 9. Aquatic risk assessment strategy plan for surfactants 


\begin{tabular}{|c|c|c|c|c|}
\hline $\begin{array}{c}\text { PEC } \\
\text { surface water }\end{array}$ & EC50/NOEC & $\begin{array}{l}\text { Application factors for } \\
\text { the lowest EC50 / NOEC }\end{array}$ & $\begin{array}{l}\text { PNEC surface } \\
\text { water }\end{array}$ & $\begin{array}{l}\text { Risk coefficients } \\
\text { (PEC/PNEC) }\end{array}$ \\
\hline \multirow{5}{*}{$\begin{array}{c}P E C_{\max }=0.2 \mathrm{mg} / \mathrm{L} \\
{[12]}\end{array}$} & & 100 (OECD) & 0.0039 & 51.28 \\
\hline & 0.39 mg/L (algae) [84] & $1000(\mathrm{EU})$ & 0.00039 & 512.20 \\
\hline & & 200 (ECETOC) & 0.00195 & 102.56 \\
\hline & 0.004 mg/L (Daphnia) [12] & 10 (OECD and EU) & 0.0004 & 500 \\
\hline & 0.05 mg/L (algae) [84] & 100 (OECD) & 0.0005 & 400 \\
\hline \multirow{5}{*}{$\begin{array}{c}P E C_{\min }=0.002 \mathrm{mg} / \mathrm{L} \\
{[12]}\end{array}$} & & $100(\mathrm{OECD})$ & 0.0039 & 0.51 \\
\hline & 0.39 mg/L (algae) [84] & $1000(\mathrm{EU})$ & 0.00039 & 5.12 \\
\hline & & 200 (ECETOC) & 0.00195 & 1.025 \\
\hline & 0.004 mg/L (Daphnia) [12] & 10 (OECD and EU) & 0.0004 & 5 \\
\hline & 0.05 mg/L (algae) [84] & 100 (OECD) & 0.0005 & 4 \\
\hline \multirow{5}{*}{$\begin{array}{c}\mathrm{PEC}_{\max }=0.01 \mathrm{mg} / \mathrm{L} \\
\text { (Danube River } \\
\text { Romania) }\end{array}$} & & 100 (OECD) & 0.0039 & 2.56 \\
\hline & 0.39 mg/L (algae) [84] & $1000(\mathrm{EU})$ & 0.00039 & 25.64 \\
\hline & & 200 (ECETOC) & 0.00195 & 5.12 \\
\hline & 0.004 mg/L (Daphnia) [12] & 10 (OECD and EU) & 0.0004 & 25 \\
\hline & 0.05 mg/L (algae) [84] & 100 (OECD) & 0.0005 & 20 \\
\hline
\end{tabular}

Table 10. Risk coefficients assessment for quaternary ammonium salts (eg. benzenthonium chloride / Hyamine 1622, CAS: 121-54-0) according to OECD, EC and ECETOC

\begin{tabular}{|c|c|c|c|c|}
\hline $\begin{array}{c}\text { PEC } \\
\text { surface water }\end{array}$ & EC50/NOEC & $\begin{array}{l}\text { Application factors for } \\
\text { the lowest EC50 /NOEC }\end{array}$ & $\begin{array}{c}\text { PNEC surface } \\
\text { water }\end{array}$ & $\begin{array}{l}\text { Risk coefficients } \\
\text { (PEC/PNEC) }\end{array}$ \\
\hline \multirow{5}{*}{$\begin{array}{c}\mathrm{PEC}_{\max }=0.002 \mathrm{mg} / \mathrm{L} \\
\text { (Danube River } \\
\text { Romania) }\end{array}$} & & 100 (OECD) & 0.055 & 0.036 \\
\hline & 5.55 mg/L (algae) [84] & $1000(\mathrm{EU})$ & 0.0055 & 0.36 \\
\hline & & 200 (ECETOC) & 0.027 & 0.074 \\
\hline & 0.5 mg/L (algae) [84] & 100 (OECD) & 0.005 & 0.4 \\
\hline & $0.09 \mathrm{mg} / \mathrm{L}$ (algae) [**] [30] & 10 (OECD / EU) & 0.009 & 0.22 \\
\hline \multirow{5}{*}{$\begin{array}{c}P E C_{\min }=0,0019 \mathrm{mg} / \mathrm{L} \\
{[13]}\end{array}$} & & 100 (OECD) & 0.055 & 0.034 \\
\hline & 5.55 mg/L (algae) [84] & 1000 (EU) & 0.0055 & 0.34 \\
\hline & & 200 (ECETOC) & 0.027 & 0.07 \\
\hline & 0.5 mg/L (algae) [84] & 100 (OECD) & 0.005 & 0.38 \\
\hline & 0.09 mg/L (algae) [30] & 10 (OECD / EU) & 0.009 & 0.21 \\
\hline
\end{tabular}

Table 11. Risk coefficients assessment for coco alkyl derives (eg. Cocamidopropylbetaine / AMFODAC LB, CAS: 4292-10-8) according to OECD, EC and ECETOC 


\section{Future challenges}

The surfactants ecotoxicology domain remain open for new researches, because this compounds are in a dynamic change of molecular structure which can modified the level of biodegradability and toxicity. It is necessary to develop new control analytical methods for all type of surfactants (HPLC, LC / ELSD, LC-(ESI) MS). Some problems were highlighted concerning the strong absorption capacity of surfactants on the active sludge and also will be interesting to study the impact of cationic and amphoteric surfactants on sludge microorganisms.

There are still gaps in ecotoxicological and risk assessment databases of cationic and amphoteric surfactants, and also for the several nonionic surfactants. Also, an important subject in this research field is the study of biotic and abiotic factors influence on the bioavailability of surfactant compounds.

A great attention should be given to monitoring studies of the surfactants in the national and international surface waters, in order to underline the level of domestic and industrial pollution with this compounds and also to upgrade the current legislation or if is necessary to replace them.

In this field are significant gaps concerning the bioconcentration, bioaccumulation, acute and chronic sub lethal effects and the impact of surfactants on the metabolic pathways, whatever of surfactant type.

Another limitation of this research was the detection of metabolic compounds resulted after biodegradation process, which requires completion of equipment endowment and involve new expenses.

\section{Conclusions}

The aim of this chapter was the cationic and amphoteric surfactants ecotoxicological characterization according to European Regulation EC no. 648/2004 and risk assessment generated by them on the aquatic environment. Experimental researches were performed to establish the biodegradation level and aquatic toxicity, risk assessment and estimation of the maximum allowable limits in surface water.

Has been pointed that the cationic and amphoteric surfactants have a primary biodegradation $>80 \%$ and a final removal $>60 \%$, noting that the cationic surfactants have registered the lowest values. In terms of acute aquatic toxicity was found that cationic surfactants are toxic for crustaceans, algae and bacteria ("Acute Toxicity, class 1") and amphoteric surfactants are toxic to fish, crustaceans and algae ("Acute Toxicity, class 2").

A complementary risk assessment study was performed for biodegradation liquids of cationic surfactants. The biodegradation effluents maintain the compounds toxicity on algae and bacteria in case of standard surfactant (Hyamine 1622), which means that in the surfactant 
biodegradation effluents the active substance was persistent or can arise recalcitrant metabolites.

Based on PEC / PNEC ratios, the aquatic risk assessment of cationic and amphoteric surfactants has been assessed: cationic surfactants PEC / PNEC > 1 - risk to aquatic organisms; amphoteric surfactant PEC / PNEC $<1$ - no risk to aquatic organisms.

Were estimated maximum allowable concentrations (MATC) of cationic surfactants $(\leq 0.002$ $\mathrm{mg} / \mathrm{L})$ and amphoteric $(0.01 \mathrm{mg} / \mathrm{L})$ in surface waters, so that the aquatic life in trophic chain, will not be affected.

The present study was relevant for the conformity control of market cleanup products to assure the human health and environment protection.

\section{Abbreviations}

AISE - International Association for Soaps, Detergents and Maintenance Products;

CEFIC - European Chemical Industry Council;

CESIO - European Committee of Organic Surfactants and their Intermediates;

EC - European Commission;

$\mathrm{EC}_{50}$ - lethal or inhibitory Effective Concentration with $50 \%$ effect on crustacean, algae or bacteria;

ECETOC - European Centre for Ecotoxicological \& Toxicological Safety Assessment of Chemicals;

ECVAM - The European Centre for the Validation of Alternative Methods;

EPA - US Environmental Protection Agency;

GHS - Globally Harmonized System for Classification and Labeling of Chemicals;

HERA - Human and Environmental Risk Assessment on ingredients of European household cleaning products;

ICCVAM - Interagency Coordinating Committee on the Validation of Alternative Methods;

ISO - The International Standardization Organization;

IUCLID - International Uniform Chemical Information Database;

$\mathrm{LC}_{50}$ - Lethal Concentration with $50 \%$ effect on fish;

LOEC - Lowest Observed Effect Concentration

NICNAS - National Industrial Chemicals Notification and Assessment Scheme;

NOEC - No Observed Effect Concentration; 
OECD - Organization for Economic Co - operation and Development;

Q(SAR) - Quantitative Structure Activity Relationship;

REACH - Regulation concerning Registration, Evaluation, Authorization and Restriction of Chemicals Substances;

SETAC - Society of Environmental Toxicology and Chemistry;

\section{Acknowledgements}

Authors thanks to National Research and Development Institute for Industrial Ecology ECOIND and University of Bucharest for financial and technical support of this research.

\section{Author details}

Stefania Gheorghe*, Irina Lucaciu, Iuliana Paun, Catalina Stoica and Elena Stanescu

*Address all correspondence to: stefania_ivan2005@yahoo.com

National Research and Development Institute for Industrial Ecology - ECOIND Bucharest, Romania

\section{References}

[1] Berger, H. Environmentally compatible surfactants for the cosmetic industry, presented at the SCS Symposium Bristol 7-8 April 1997 Int. Journal of Cosmetic Science (1997). , 19, 227-237.

[2] Longman, G. F. The analysis of Detergents and Detergents Products; (1975).

[3] Regulation (EC) noof European Parliament and European Council, Official Journal of European Union, L104/1, April (2004).

[4] Regulation (EC) no the first Amendment of Regulation (2004). (648), 2006.

[5] Communities European CommissionCommission Recommendations from 23/XII/ 2005 concerning- the technical guidance for stratified approach of Regulation (CE) of implementation, Bruxelles, C (2005) 5677 final; (2005). (648)

[6] Regulation (EC) no. 66/2010 of the European Parliament and of the Council of 25 November 2009 concerning the EU ecological labeling.

[7] http://uk.cleanright.eu/ (accessed 12 November 2012). 
[8] http://www.cefic-lri.org (accessed 12 November 2012).

[9] Ute MB and Erich J. Anaerobic Biodegradation of Detergent Surfactants, Materials $2009 ; 2,181-206$.

[10] Tomislav I. and Hrenovic J. Surfactants in the Environment, Arh. Hig. Rada Toksicol 2010; 61, 95-110.

[11] HERA, Esterquats - Environmental Risk Assessment Report. Edition 1.0, March 2008.

[12] NICNAS, Full public report for Stepantex Esterquat, 28 January 2003.

[13] Kazuaki M, Naohiro N and Akiko Y. Aquatic environmental monitoring of detergent surfactants, Jurnal of Oleo Science 2008; 57(3)161-170.

[14] Detergent Products Environmental Project, Environmental and Health Assessment of Substances in Household Detergents and Cosmetic, 615; 2001.

[15] Séné C. Regulatory compliance of surfactants: Testing of surfactants and how the surfactant industry plans the implementation of Regulation. Workshop on the Implementation of Detergents Regulation (INFRA 32637), Bucharest, Romania; 2009.

[16] Gheorghe S, Lucaciu I, Grumaz R. Detergents legislative framework and ecotoxicological testing methodology. Journal of Environmental Protection and Ecology; 2011, book 3A(12)1525-1532.

[17] Domsch A and Klaus J. Biodegradability of amphoteric surfactants, in Karsa DR and Porter MR(eds.), Biodegradability of surfactants. Blackie Academic \& Professional, Glasgow, United Kingdom, 231-254; 1995.

[18] Biffi E. Biodegradability Tests: Test Material: ANFODAC LB. Unpublished Report (Project number 96/200.A6), Biolab, 1996.

[19] Giolando ST, Rapaport RA, Larson RJ and Federle TW. Environmental fate and effects of DEEDMAC: a new rapidly biodegradable cationic surfactant for use in fabric softeners. Chemosphere 199; 530(6)1067-1083.

[20] Unilever.The ready and ultimate biodegradability of DEEDMAC in a manometric respirometry test. Report BD-MAN-10, 1991.

[21] Puchta R, Krings P and Sandkühler P, A new generation of softeners. Tenside Surf. Det. 1993; 30,186-191.

[22] Comber SDW, Painter H and Reynolds P. Cationic \& Amphoteric Surfactant Primary Biodegradability Ring Test, European Union, ETD/98/502063, WRc Ref: CO 4909; 2000.

[23] Safty Datasheet STEPANTEX VL 90A, Stepan Europe; 2002. 
[24] Games LM King JE and Larson RJ. Fate and distribution of a quaternary ammonium surfactant, octadecyltrimethylammonium chloride (OTAC), in wastewater treatment. Environ. Sci. Technol. 1982; 16,483-488.

[25] Torben M, Boyd HB, Nylen D, Pedersen AR, Petersen GI and Simonsen F. Environmental and Health Assessment of Substances in Household Detergents and Cosmetic Detergent Products, Environment Project no. 615, 2001.

[26] Garcia MT, Campos E, Marsal A, Ribosa I. Fate and effects of amphoteric surfactants in the aquatic environment, Environment International 2008,34,1001-1005.

[27] Brunner C, Baumann U, Pletscher E, Eugsterm, Total degradation or environmental experiment?. Tenside Surf. Det. 2000; 37, 276-280.

[28] IUCLID Dataset: European Commission-Chemicals Bureau, CAS 6178-40-0 (Cocamidopropyl betaine), CAS 911995-81-2 and CAS 93334-15-7 (Fatty acids, C10-20 and C16-18 -unsatd. reaction products with triethanolamine, di-Me sulfate-quaternized), February 2000.

[29] EPA, Index of Robust Summaries ACCFND Amides Chemical Category, Annex A; 2001.

[30] www.lenntech.com/aquatic/detergents (accessed 23 April 2012).

[31] Abel PD, Toxicity of synthetic detergents to fish and aquatic invertebrates. Journal of Fish Biology, 1974; 6,279-298.

[32] Masayuki $Y$ and Takamasa T. Aquatic toxicity and biodegradability of advanced cationic surfactant APA - 22 compatible with the aquatic environment, Jurnal of Oleo Science 2008; 57(10)529-538.

[33] Zdenka S. Water quality and fish health, Eifac Technical Paper 54, 1993.

[34] Lewis MA. Chronic toxicities of surfactants and detergent builders to algae: A review and risk assessment, Ecotoxicology and Environmentally Safety 2004; 20(2)123-140.

[35] Pavlic Z, Zeljka VC, Dinko P. Toxicity of surfactants to green microalgae Pseudokirchneriella subcapitata and Scenedesmus subspicatus and to marine diatoms Phaeodactylum tricornutum and Skeletonema costatum, Chemosphere 2005; 61,1061-1068.

[36] Regulation (EC) no. 1907/2006 of the European Parliament and of the Council of 18 December 2006 concerning the Registration, Evaluation, Authorization and Restriction of Chemicals (REACH).

[37] Persoone G, Marsalek B, Blinova I, Törökne A, Zarina D, Manusadzianas L, Grzegorz NJ, Tofan L, Stepanova N, Tothova L, Kolar B. A practical and user-friendly toxicity classification system with microbiotests for natural waters and wastewaters, Environmental Toxicology 2003;18(6)395 - 402. 
[38] Kao Corporation SA, Safety Datasheet for TETRANYL AT-7590; 2009.

[39] Unilever.The acute toxicity of Stepantex degradation intermediate to Daphnia magna, Report no.: AT/R202/01,1989b.

[40] Unilever. The acute toxicity of Hamburg ester quat to Daphnia magna. Report no.: AT/K5/08, 1990b.

[41] Unilever.The chronic toxicity of Hamburg ester quat to Daphnia magna in ASTM medium. Report no.: CT/K5/06,1991c.

[42] Unilever. The chronic toxicity of Hamburg ester quat to Oncorhynchus mykiss 28 day growth test. Report no.: CT/K05/07,1991d.

[43] Unilever. The acute toxicity of DEEDMAC to Zebra fish. Report no.: AT/S057/0, 1996a.

[44] Unilever. The toxicity of DEEDMAC monoester to Scenedesmus subspicatus. Report no.: AL/S052/02, 1997c.

[45] Procter \& Gamble, Acute toxicity of SS0138.01 on Selenastrum capricornutum printz. Report no.: 40390, ABC Laboratories, Inc. Columbia, Missouri, 1993a.

[46] Procter \& Gamble, Chronic toxicity of SS0565.01 to Daphnia magna using natural surface water under flow-through conditions, ABC Laboratories, Inc. Columbia, Missouri, report no. 44855,1999a.

[47] Henkel KGaA. Stepantex VS 90: Algal toxicity, Department of Ecology, Düsseldorf, Germany; 1989a.

[48] Grzegorz N, Jawecki C, Ska-Sota EG and Narkiewicz P. The toxicity of cationic surfactants in four bioassays, Guidance Document Methodology, Human \& Environmental Risk Assessment on Ingredients of Household; 2005.

[49] Ying GG. Fate, behaviour and effects of surfactants and their degradation products in the environment, Environ. Int. 2006; 32(3)417-31.

[50] Stterlin H, Alexy R, Kmmerer K. The toxicity of the quaternary ammonium compound benzalkonium chloride alone and in mixture with other anionic compounds to bacteria and test systems with Vibrio fischeri and Pseudomonas putida, Ecotoxicol. Environ. Saf. 2008; 71, 498-505.

[51] Roghair CJ, Buijze A and Schoon HNP. Ecotoxicological risk evaluation of the cationic fabric softener DTDMAC. I. Ecotoxicological effects. Chemosphere 1992; 24 (5) 599609.

[52] EPA, Alkyl Dimethyl Benzyl Ammonium Chloride (ADBAC) Preliminary Risk Assessment Office of Pesticide Programs. Antimicrobials Division; 2006. 
[53] Lewis MA and Hamm BG. Environmental modification of the photosynthetic response of lake plankton to surfactants and significance to a laboratory - field comparison. Water Res. 1986; 20, 1575-1582.

[54] Lewis RJ. Sax's Dangerous Properties of Industrial Materials.9th ed. Van Nostrand Reinhold, New York, United States, 1996.

[55] Utsunomiya A, Watanuki T, Matsushita K and Tomita I. Toxic effects of linear alkylbenzene sulfonate, quaternary alkylammonium chloride and their complexes on Dunaliella sp. and Chlorella pyrenoidosa. Environ. Toxicol. Chem. 1997; 16, 1247-1254.

[56] Toxicology/Regulatory Services, Inc., Fatty Nitrogen Derived Cationics Category High Production Volume (HPV) Chemicals Challenge, Test Plan, 2001.

[57] Berol N. Amphoteen 24, Produkt information (in Swedish); 1993.

[58] Brøste P, Brugsanvisning for Dehyton AB 30 (in Danish). Materials safety data sheet for Dehyton AB 39. P. Brøste A/S, Lyngby, Denmark; 1998.

[59] Iancu V. Study of HPLC analitical determination of cationic and amphoteric surfactants in aqueous solutions. In house paper, June 2007.

[60] Ciurcanu I, Lucaciu I, Mihaila E. Experimental research to elaborate and verify a spectrophotometer method for the determination of cationic surfactants concentration in aqueous solution, proceedings of the International Symposium "Environment and Industry" 29 - 31 October 2003, Bucharest, Romania; 2003.

[61] Bratucu L, Ciurcanu I, Lucaciu I, Mihaila E. Laboratory assimilation and implementation of analytical methods used for cationic and amphoteric surfactants concentrations assessment from aqueous solutions, proceedings of The XXIX National Conference of Chemistry, 04-06 October 2006, Ramnicu Valcea, Romania; 2006.

[62] Levsen K, Emmrich M and Behnert S. Determination of dialkyldimethylammonium compounds and other cationic surfactants in sewage water and activated sludge, Fresenius'Journal of Analytical Chemistry 2004; 732-737.

[63] Yong Q, Gaoyong Z, Baoan K, Yumei Z. Primary aerobic biodegradation of cationic and amphoteric surfactants, Journal of Surfactants and Detergents 2005; 8(1)55-58.

[64] German Standard Methods for the investigation of water, wastewater and sludge. Collective parameters for effects and substances (Group H). Determination of disulphine blue active substances (H20). DIN 38409 - Ausgabe:1989-07; Part 20.

[65] Idouhar M and Tazerouti A. Spectrophotometric determination of cationic surfactants using patent blue V: application to the wastewater industry in Algiers. Journal of Surfactants and Detergents, 2008; 11(4)263-267.

[66] OECD, Chemicals Group. Revised guidelines for tests for ready biodegradability, Paris, 1993a. 
[67] OECD 301A. Dissolved organic carbon analyze method - DOC method - Biodegradability test.

[68] OECD 301D. Assessment of ultimate aerobe biodegradability in aqueous media of organic compounds. The biochemical oxygen remove analyze method (the closed tubes test).

[69] Gheorghe S, Lucaciu I, Pascu L. Biodegradability assessment of cationic and amphoteric raw materials, Journal of Environmental Protection and Ecology 2012;13 (1)155-164.

[70] Gheorghe S, Lucaciu I, Pascu L. Removal of surfactants from household cleaning products and/or cosmetic detergents during the ready biodegradability tests performed in conformity with the new European regulations, proceedings of the International Symposium „The environment and industry” (SIMI) 28-30 October 2009, Bucharest, Romania, EstFalia; 2009.

[71] Gheorghe S, Lucaciu I, Pascu L. Ultimate biodegradability assessment of cationic and amphoteric surfactants, proceedings of the International Conference on fishery and aquaculture - a view point upon the sustainable management of the water resources in the Balkan area, 26-28.05.2010, Galati, Romania; 2010.

[72] American Society for Testing and Materials: Standard methods for conducting acute toxicity tests with fishes, macro invertebrates, and amphibians, in Annual Book of ASTM Standards. Designation E 729-88a, Philadelphia: ASTM, 1992a; 11,403-422.

[73] OECD, Guidelines for the testing of chemicals, 2006.

[74] OECD, Manual for Investigation of Hpv Chemicals, 2006.

[75] Official Journal of the European Communities: Methods for the determination of ecotoxicity, L133, pp.88-127, Office for Official Publications. L2985, Luxembourg, 1988.

[76] Governmental Decision 1408/2008 concerning the classification, labeling and packing of dangerous chemicals.

[77] Globally Harmonized System for Classification and Labeling of Chemicals (GHS), revision 4, United Nations, New York and Geneva, 2011; www.unece.org (accessed 12 May 2012).

[78] CESIO, Environmental Risk Assessment of Detergent Chemicals, Proceedings of the AISE/CESIO Limelette III Workshop, 28-29 November 1995, Brussels; 1996.

[79] HERA, Cocoamidopropyl Betaine (CAPB).Edition 1.0, June 2005.

[80] Ivan (Gheorghe) S., Determination of cationic and amphoteric surfactants ecotoxicity and their aquatic risk assessment, $\mathrm{PhD}$ thesis. Bucharest University and INCD ECOIND Bucharest;2012. 
[81] Leeuwen K, Roghair C, Nijs T and Greef J. Ecotoxicological risk evaluation of the cationic fabric softener DTDMAC. III. Risk assessment, Chemosphere 1992; 24 (5)629-639.

[82] Notox BV. Safety and Environmental Research, New Detergent Regulation published in the Official Journal, Effective on 8th October 2005.

[83] Technical Guidance Document on Risk Assessment, European Chemicals Institute for Health and Consumer Protection Bureau, Part II, 2003.

[84] Gheorghe S, Lucaciu I, Grumaz R, Stoica C. Acute toxicity assessment of several cationic and amphoteric surfactants on aquatic organisms, Journal of Environmental Protection and Ecology 2012;13(2) 541-553. 